NBER WORKING PAPER SERIES

\author{
DEFACTO AND DEEDED INTELLECTUAL PROPERTY: \\ KNOWLEDGE-DRIVEN CO-EVOLUTION OF \\ FIRM COLLABORATION BOUNDARIES AND IPR STRATEGY
}

\author{
Lynne G. Zucker \\ Michael R. Darby \\ Working Paper 20249 \\ http://www.nber.org/papers/w20249
}

\author{
NATIONAL BUREAU OF ECONOMIC RESEARCH \\ 1050 Massachusetts Avenue \\ Cambridge, MA 02138 \\ June 2014
}

This research has been supported by grants from the National Science Foundation (grants SES 0304727, SES-0830983, and SES-1158907) and the Ewing Marion Kauffman Foundation (grants 2008-0028 and 2008-0031). We are indebted to our research team members Minji Kang, Hsing-Hau Chen, Jason Fong, Nahoko Kameo, Amarita Natt, and Yong Yang. We acknowledge valuable comments on earlier versions of this paper by referees for the Annals of Economics and Statistics special issue on emerging industries, at the Princeton University-Microsoft Intellectual Property Conference, and at seminars given at the University of Michigan, UC San Diego, UC Irvine and UCLA. We received especially on point comments from participants at two JST International Workshops "Towards Evidence-based Policy for Science, Technology and Innovation Policy" and "Measuring and Managing Innovation Process" in Tokyo, the USPTO's Patent Statistics for Decision Makers Conference, and the STAR Metrics II Workshop. Detailed comments from colleagues, especially Matthew Kahn, helped shape the paper. Certain data included herein are derived from the Science Citation Index Expanded, Social Sciences Citation Index, Arts \& Humanities Citation Index, High Impact Papers, and ISI Highly Cited of the Institute for Scientific Information ${ }^{\circledR}$, Inc. (ISI $\left.{ }^{\circledR}\right)$, Philadelphia, Pennsylvania, USA: ${ }^{C}$ Copyright Institute for Scientific Information ${ }^{\circledR}$, Inc. 2005, 2006. All rights reserved. Certain data included herein are derived from the Connecting Outcome Measures of Entrepreneurship, Technology, and Science (COMETS) database and the associated COMETSbeta and COMETSandSTARS databases (C) Lynne G. Zucker and Michael R. Darby. All rights reserved. This paper is a part of the NBER's research program in Productivity. Any opinions expressed are those of the authors and not those of their employers or the National Bureau of Economic Research. The views expressed herein are those of the authors and do not necessarily reflect the views of the National Bureau of Economic Research.

NBER working papers are circulated for discussion and comment purposes. They have not been peerreviewed or been subject to the review by the NBER Board of Directors that accompanies official NBER publications.

(C) 2014 by Lynne G. Zucker and Michael R. Darby. All rights reserved. Short sections of text, not to exceed two paragraphs, may be quoted without explicit permission provided that full credit, including (C) notice, is given to the source. 
Defacto and Deeded Intellectual Property: Knowledge-Driven Co-Evolution of Firm Collaboration Boundaries and IPR Strategy

Lynne G. Zucker and Michael R. Darby

NBER Working Paper No. 20249

June 2014

JEL No. J44,L25,L63,L64,L65,M13,O31,O32,O33,O34

\begin{abstract}
Research on intellectual property has focused on formal legally recorded rights that we call deeded, most often measured by granted patents. Meanwhile, other "defacto" IP (mainly purposive secrecy and natural excludability) has become more important because of the increasing closeness of commercial technologies to cutting edge science. A "corporate-academic" model has developed and become institutionalized over the last three decades which emphasizes attracting the best and brightest scientists, providing them with a commensurate increase in autonomy including initiation of bench-level collaborations with top university scientists in which valuable tacit knowledge is transferred in both directions. We provide suggestive evidence that both firm and university scientists learn from these collaborations, e.g., both types of scientists experience sharply higher patenting rates once they have engage in university-firm collaborations. We propose and test two indicators of adoption of the corporate-academic model, whether or not the firm has ever: (a) co-authored an article with a university scientist and (b) applied for (an eventually granted) patent with non-patent references, where these references are used importantly to cite scientific articles and other scientific materials. Both were robustly positive and statistically significant across four measures of U.S. high-tech firm success (publishing, patenting, obtaining venture capital, and going public) for six broad S\&T areas (bio/chem/med, information technology, nanotechnology, semiconductors, other science, and other engineering). Star scientists publication as or with firm employees, SBIR grants received, and citation-weighted patents and articles all played comparatively supporting roles in the empirical estimates. We concluded that the most successful high-tech firms have adopted a strategy of operating near the edge of the scientific envelope where high levels of tacit knowledge provide substantial natural excludability reducing or preventing entry of imitators.
\end{abstract}

Lynne G. Zucker

Departments of Sociology \& Public Policy

UCLA

Box 951551

Los Angeles, CA 90095-1551

and NBER

zucker@ucla.edu

Michael R. Darby

John E. Anderson Graduate School of Management

University of California, Los Angeles

110 Westwood Plaza, Box 951481

Los Angeles, CA 90095-1481

and NBER

michael.r.darby@anderson.ucla.edu 


\title{
Defacto and Deeded Intellectual Property: Knowledge-Driven Co-Evolution of Firm Collaboration Boundaries and IPR Strategy*
}

\author{
Lynne G. Zucker and Michael R. Darby
}

\section{Introduction}

Are basic science and industrial innovation growing closer to each other? There is some evidence that it is in the research reported here, and in a number of other recent studies. But most of the evidence from other work comes from the patent side - focusing recently especially on the inclusion of scientific articles under "Other References" on patents. However, this focus on deeded intellectual property leaves out a range of defacto intellectual property including natural excludability, which firms have increasingly used, as well as trade and actual secrecy. These intellectual property rights, or IPRs, prevent imitators from competing away the rents necessary to induce sufficient investment in inventions to bring the successful ones to market as the innovations which ultimately drive growth in wages, GDP, and our standard of living. We present evidence here that as technology has moved closer to cutting edge science, defacto IP has become increasingly important in practice and has long been more important than deeded IP in a number of industries. We believe we make a case for broadening our understanding of intellectual property beyond the proverbial lamppost of patents.

Why study emergent technology areas where scientific breakthroughs have just been made? The creative destruction that takes place under these conditions is one fundamental reason (Schumpeter 1942, Aghion and Howitt 1992), but we propose that more attention should be focused on the "creative construction" part: the emergence of new structures and mechanisms, primarily in new firms but also in transformed existing firms (Romanelli 1991, Liebeskind,

\footnotetext{
*This research has been supported by grants from the National Science Foundation (grants SES 0304727, SES-0830983, and SES-1158907) and the Ewing Marion Kauffman Foundation (grants 2008-0028 and 2008-0031). We are indebted to our research team members Minji Kang, Hsing-Hau Chen, Jason Fong, Nahoko Kameo, Amarita Natt, and Yong Yang. We acknowledge valuable comments on earlier versions of this paper by referees for the Annales special issue on emerging industries, at the Princeton University-Microsoft Intellectual Property Conference, and at seminars given at the University of Michigan, UC San Diego, UC Irvine and UCLA. We received especially on point comments from participants at two JST International Workshops "Towards Evidence-based Policy for Science, Technology and Innovation Policy" and "Measuring and Managing Innovation Process" in Tokyo, the USPTO's Patent Statistics for Decision Makers Conference, and the STAR Metrics II Workshop. Detailed comments from colleagues, especially Matthew Kahn, helped shape the paper. Certain data included herein are derived from the Science Citation Index Expanded, Social Sciences Citation Index, Arts \& Humanities Citation Index, High Impact Papers, and ISI Highly Cited of the Institute for Scientific Information ${ }^{\circledR}$, Inc. (ISI $\left.{ }^{\circledR}\right)$, Philadelphia, Pennsylvania, USA: ${ }^{\circ}$ Copyright Institute for Scientific Information ${ }^{\circledR}$, Inc. 2005, 2006. All rights reserved. Certain data included herein are derived from the Connecting Outcome Measures of Entrepreneurship, Technology, and Science (COMETS) database and the associated COMETSbeta and COMETSandSTARS databases (C Lynne G. Zucker and Michael R. Darby. All rights reserved. This paper is a part of the NBER's research program in Productivity. Any opinions expressed are those of the authors and not those of their employers or the National Bureau of Economic Research.
} 
Oliver, Zucker and Brewer 1996, Zucker and Darby 1996, 1997). These are the building blocks of emerging firms and, in some cases, new industries that incorporate very different technological bases and activities, even when end products have a similar function.

We start our story here with the biotechnology revolution that replaced chemically-based pharmaceuticals with biologically-based ones, using radically different drug discovery tools and adding new, fermentation-based, manufacturing technologies. It was in the course of this revolution that many of the significantly new structures and mechanisms we examine here were either initially or further developed. From the experience of the formation/reconstitution of this industry, a more fundamental understanding was developed of how to source highly tacit external knowledge both effectively and with acceptable risk. This is difficult to accomplish when transmission generally requires face-to-face joint research, most often at the lab bench. One indicator of the risk is that joint ventures between firms rarely engage in basic research. ${ }^{1}$

In the research reported here we show that two mechanisms identified as important early in the development of the biotechnology industry - but not frequently found at that time in other high technology firms and areas - have become increasingly important for most, though not all, areas of high technology: First, hands-on involvement of university faculty and stars in collaborations, and often leadership of research teams, in the firm (Zucker, Darby and Armstrong 1998, 2002, Powell, White, Koput, Owen-Smith 2005, Oliver 2004, Kreiner and Schultz 1993, Pisano 1990), and second, integration of highly tacit knowledge into patents via non-patent references including research articles. Non-patent references yield arguably stronger protection of the broader knowledge now embedded in the patent (Branstetter 2005, Branstetter and Ogura 2005, Narin, Hamilton and Olivastro 1997). ${ }^{2}$ Validating the decisions to adopt these mechanisms more widely across industries, we provide evidence in the results section below that private firms gain significant competitive advantage from one or both of these mechanisms across most science and technology areas. ${ }^{3}$

Before turning to a more detailed discussion of the two mechanisms we have just briefly introduced and their effect on firm success, we will now outline a few concepts that we will return to often in the course of discussing the research reported here. Information refers to separable pieces of knowledge that do not require further information of any type to use that bit or byte of data. There seems to be an implicit assumption that cumulative and/or complex information is simply more of the same, and thus readily accessible to others rather than an excludable good. Knowledge is defined as either: (1) The result of cumulative, sequenced

\footnotetext{
${ }^{1}$ Source: recent tabulations by the authors from COMETSandSTARS of joint ventures doing team science.

${ }^{2}$ We also predict by implication, but do not test here, that there is some protection for IP in related research articles cited in the patent's "Other References" section, by serving to widen the scope of patent protection. These articles may contain knowledge not yet protected by patents.

${ }^{3}$ Clusters of six areas, comparable across science and technology structures and activities that include journal articles, patents, grants, and measures of firm success, as defined in Darby and Zucker 1999.
} 
learning, required to acquire and use the information in practice, and also to use this information and its implications to further develop the body of knowledge, and/or (2) Highly complex, interrelated information that is difficult to parse out and understand by reducing it to its components. This "embedded" type of knowledge may implicitly define the relevance of different pieces of information for each other and also define relevance to the whole body of related knowledge. In both cases, the sum is greater than the parts because the interrelation of the different pieces of information, as well as an understanding of how to use it in practice, is crucial to developing the body of knowledge further.

Thus, we define knowledge as distinct from information. We have asserted with some evidence that knowledge is often naturally excludable due to its tacitness and also by virtue of its social production that is often bounded by teams, professions, organizations, and cultures (Zucker, Darby and Brewer 1998, Zucker, Darby, Brewer and Peng 1996, Zucker, Darby and Torero 2002). We expect our findings to hold under the following two conditions: first, when firms working in a new area of technology face similar organizational challenges in developing a knowledge stream and, second, when that knowledge stream is similar in both moderate to high degree of tacitness and in expected value. Tacit knowledge, whether conscious or not, is difficult to communicate effectively: Parts of tacit knowledge with low value are probably never communicated to others, while new tacit knowledge with high value will generally be communicated with a lag due to competing, higher value, uses of that knowledge. Highly tacit knowledge is best transmitted after partial codification - concepts, formulae, machines - are developed to help transmit it (Zucker, Darby and Armstrong 2002 and Figure 5 below).

\section{Motivation}

Our research is motivated by a desire to understand the development and routinization of two primary mechanisms. The first mechanism, shown on the right side of Figure 1, is a set of practices that encourage close working relationships among scientists who are part of a wider "invisible college" of scientists (Crane 1969, 1972), and, if the area is ripe for commercialization, yields many university-firm joint articles. This mechanism is amplified by adoption by firms of a variant of the academic university model, grafted on when knowledge discovery, as well as commercialization, is a central function of the firm (Liebeskind, Oliver, Zucker and Brewer 1996, Oliver and Montgomery 2000, Baker, Miner and Eesley 2003, Oliver 2004; Kreiner and Schultz 1993; Powell, White, Koput, Owen-Smith 2005).

In what we will term the "corporate-academic" form, scientists working in the firm often face few restrictions on their research activities and output: they may initiate collaborations with outside scientists, may send out for publication within three months or so after discovery (with 
corporate lawyers filing for patents within these time constrains), and can propose research agendas and continue along the approved research path with low oversight. ${ }^{4}$

Figure 1: Basic Science Discoveries and Knowledge Impacts on High-Tech Firm Success

\begin{tabular}{|c|}
\hline Patent Institutional Evolution \\
\hline $\begin{array}{c}\text { Integrated scientific articles \& other materials } \\
\text { as non-patent references (NPRs) }\end{array}$ \\
\hline
\end{tabular}

NPRs Become More Frequent in Patents NPRs citing firms' scientific publications support defense of wider claims \& invention

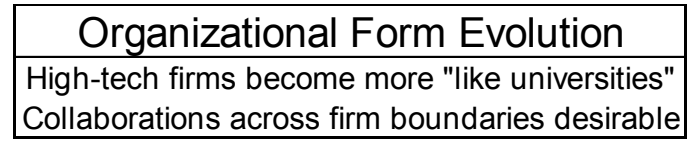

Co-Authorhips with University Scientists

Firm scientists good enough to both attract contribute to work with university scientsts

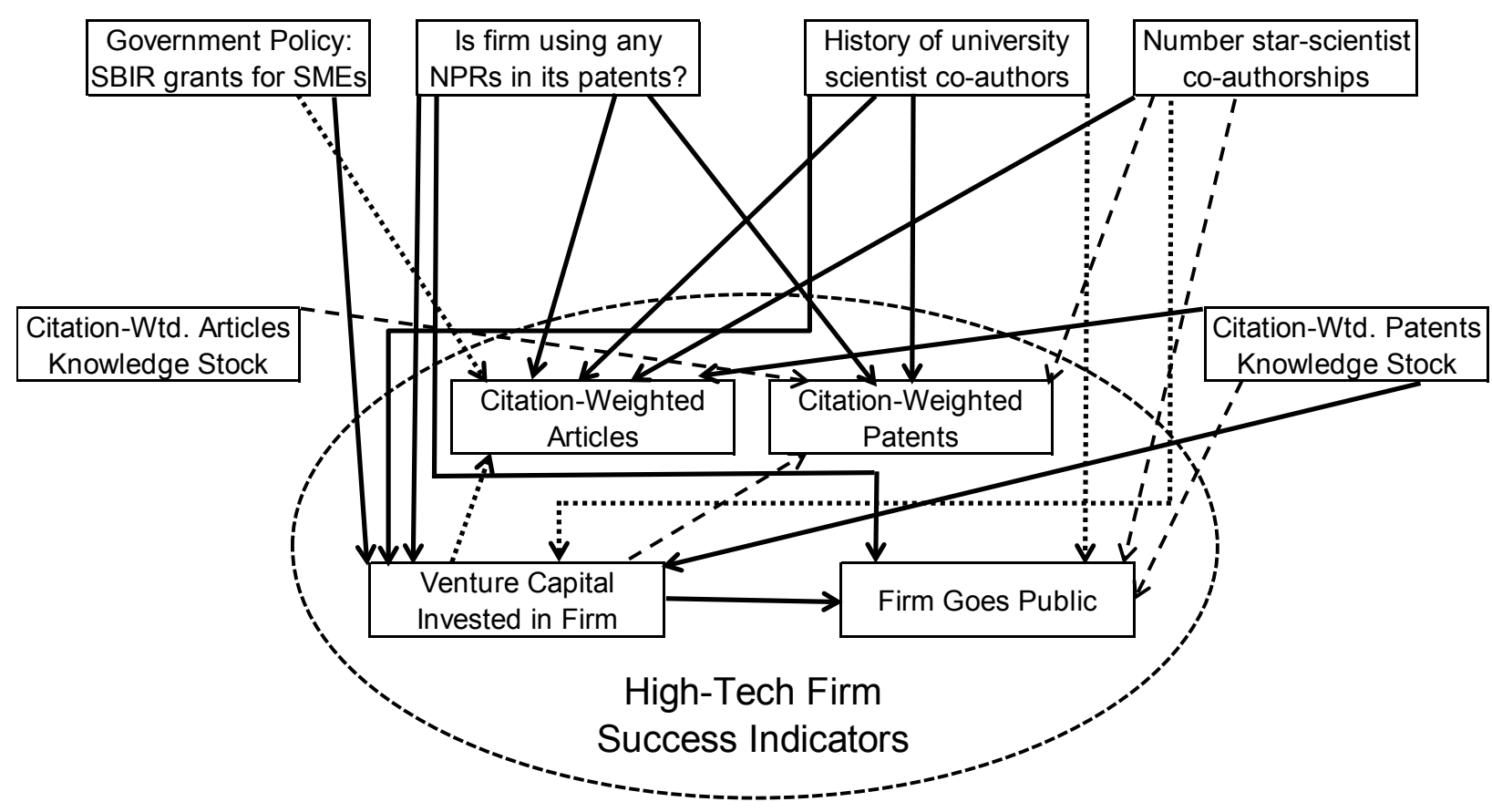

Legend: Effects characterized by pattern of signicant coefficients for variable across 6 S\&T area estimates.

$\longrightarrow$ Robust effect: $\quad 5-6$ significantly positive coefficients and 0 significantly negative coefficients

$--\rightarrow$ Probable effect: 3-4 significantly positive coefficients and 0 significantly negative coefficients

$\cdots \cdots \rightarrow$ Possible effect: $\quad 1-2$ significantly positive coefficients and 0 significantly negative coefficients

In this "corporate-academic" model, scientists have a great deal of control over their own work and the conditions under which it is performed. This new model contrasts sharply with

\footnotetext{
${ }^{4}$ These internal firm proposals are typically 3-5 page documents that replace the 20-50 page and more research proposals to external granting agencies in the pure academic organizational form (Source: authors' own interviews with start-up firms, analysis of data in the BioScan directory 1989-1997, and Oliver 2009). These projects usually continue to be funded until the firm and/or science advisory panel evaluates progress as insufficient or the research path as not promising.
} 
earlier "scientists in industry" models, where scientists were employed under non-scientist bureaucrats who controlled their research agendas and goals but were without necessary science or engineering training and experience, giving the scientists little voice in the content of their own work (Marcson 1960 and 1961; Kornhauser 1962). Outside scientific collaborations were few and were subject to this same heavy control, often unattractive to external top scientific talent.

A large body of research that we and others have published builds a strong foundation for inference about the importance of top scientists and about the kind of knowledge transfer that can only occur with frequent, close working relationships, most commonly identified through jointly published research articles or jointly invented patents (Zucker, Darby and Armstrong 1998, 2002, Mansfield 1995, Azoulay, Graff Zivin and Wang 2010, Azoulay, Graff Zivin and Sampat 2014, Powell, White, Koput, Owen-Smith 2005, Zucker, Darby and Torero 2002). We believe that this need for close working relationships with university faculty - who are compensated in various ways - accounts for the geographic localization of knowledge found by Jaffe (1989) and his many followers. ${ }^{5}$

The second mechanism, found on the left side of Figure 1, is an elaboration and institutionalization of a legal practice to incorporate highly tacit knowledge, possibly expanding the range/scope of a largely codified patent by listing relevant research articles and other scientific materials (e.g., GenBlast searches) under "Other References” on the patent's front page.

Figure 2 provides strong evidence of evolution in the content of patents towards more widespread use of scientific articles and other non-patent references across all areas of science except for semiconductors. Between 2004 and 2010, the percentage of all patents which have non-patent references rose by another 8.5 percentage points to over 65 percent, which is 4.4 times the rate observed in 1975. Bio/Chem/Med has the same upward trend as Computing/IT, Nanotechnology, Other Science and - to some degree - Other Engineering, but these last four areas collectively accounted for most of the recent increase in the use of non-patent references, including research articles.

Figures 3 and 4 provide preliminary, striking evidence of the micro-processes that underlie the change in practices and success of scientists who work across the boundaries between firms and universities, using data from our large database, COMETSandSTARS. ${ }^{6}$ These two sets of nested graphs visually present our initial results from a wider quantitative study of the micro-processes that underlie the effects of star scientist-firm and university-firm co-publishing that we report below in our tables. While nearly 10 million scientists publish and/or patent in the

${ }^{5}$ Zucker, Darby and Armstrong (1998) is focused on developing this argument and providing evidence for market-based diffusion of tacit knowledge. The spillovers (correctly, positive externalities) from academic research come through articles and patent disclosures which do not imply geographic localization (unless published only in an obscure language).

${ }^{6}$ Watch Kauffman.org/COMETS and nanobank.org for further planned data releases from the COMETSandSTARS foundational source. 
Zucker-Darby COMETSandSTARS database, only $4.7 \%$ of these scientists both publish and patent. What is the effect of boundary-spanning on firm and university patent output?

Figure 2: Percentage of Patents Assigned to U.S. Firms with Any Non-Patent References, 1975-2004

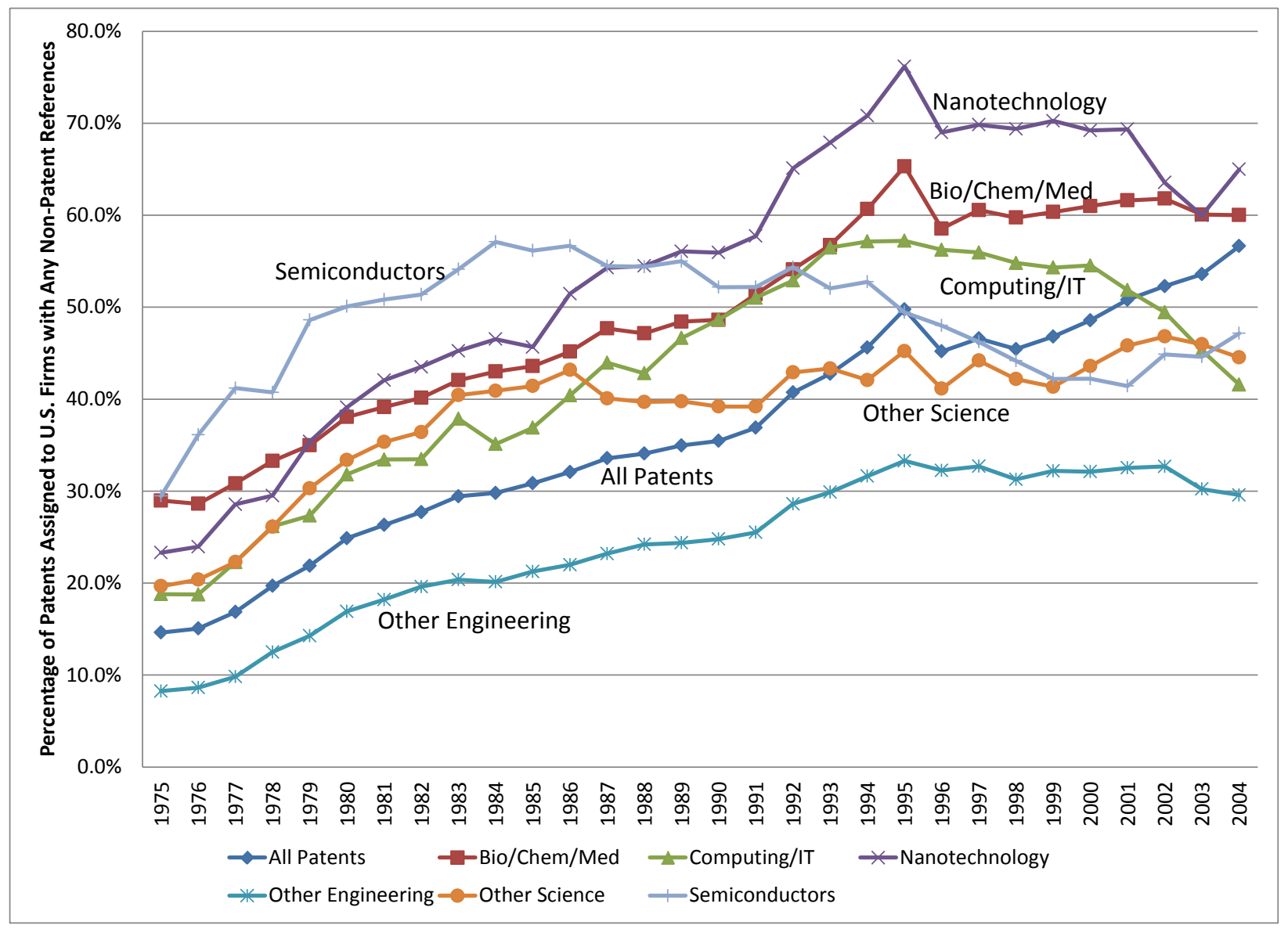

Specifically, in Figure 3 we find preliminary evidence that firm scientists who cross university-firm boundary through co-authoring or co-inventing patent more. Moving to the next figure, we also see that boundary spanning has the same effect on patenting by university scientists as we see in Figure 3 for firm scientists: Figure 4 shows that the probability of patenting for university scientists is substantially higher if they have prior firm co-publishing or co-patenting ties, compared to those without. So this is not simply sorting out university scientists who are better than firm scientists, or the firm scientists that are better than university scientists, but rather provides evidence of a more general effect of crossing the university-firm boundary on patenting. This is in line with some earlier results that show increased publishing for university biotech stars during and after firm ties (Zucker and Darby 2007). 
Figure 3: Firm Scientists with Prior Co-Authoring or Co-Inventing Ties to Universities Are More Likely to Patent than Those Firm Scientists without Those Links

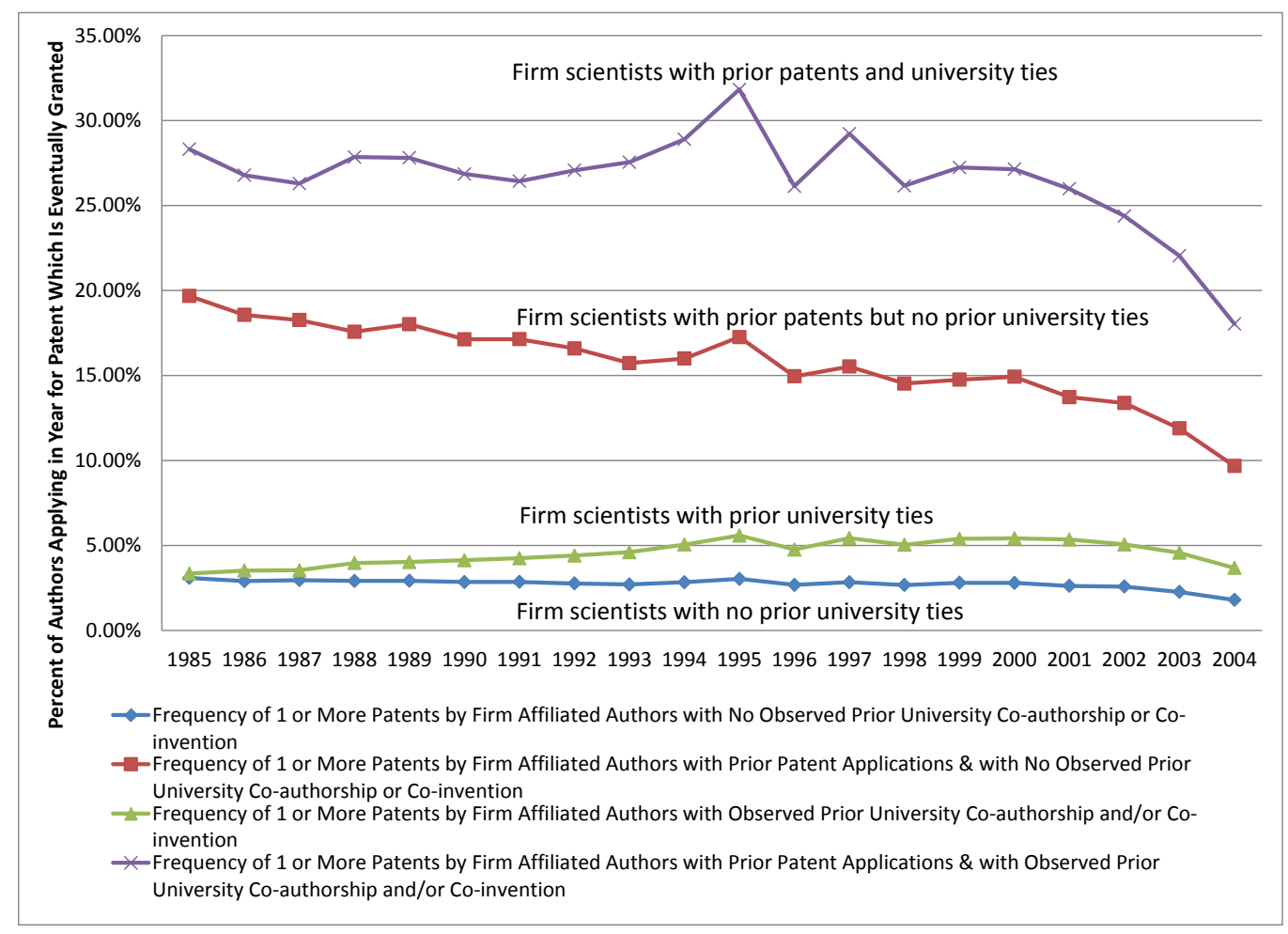

Figure 4: University Scientists with Prior Co-Authoring or Co-Inventing Ties to Firms Are More Likely to Patent than Those University Scientists without Those Links

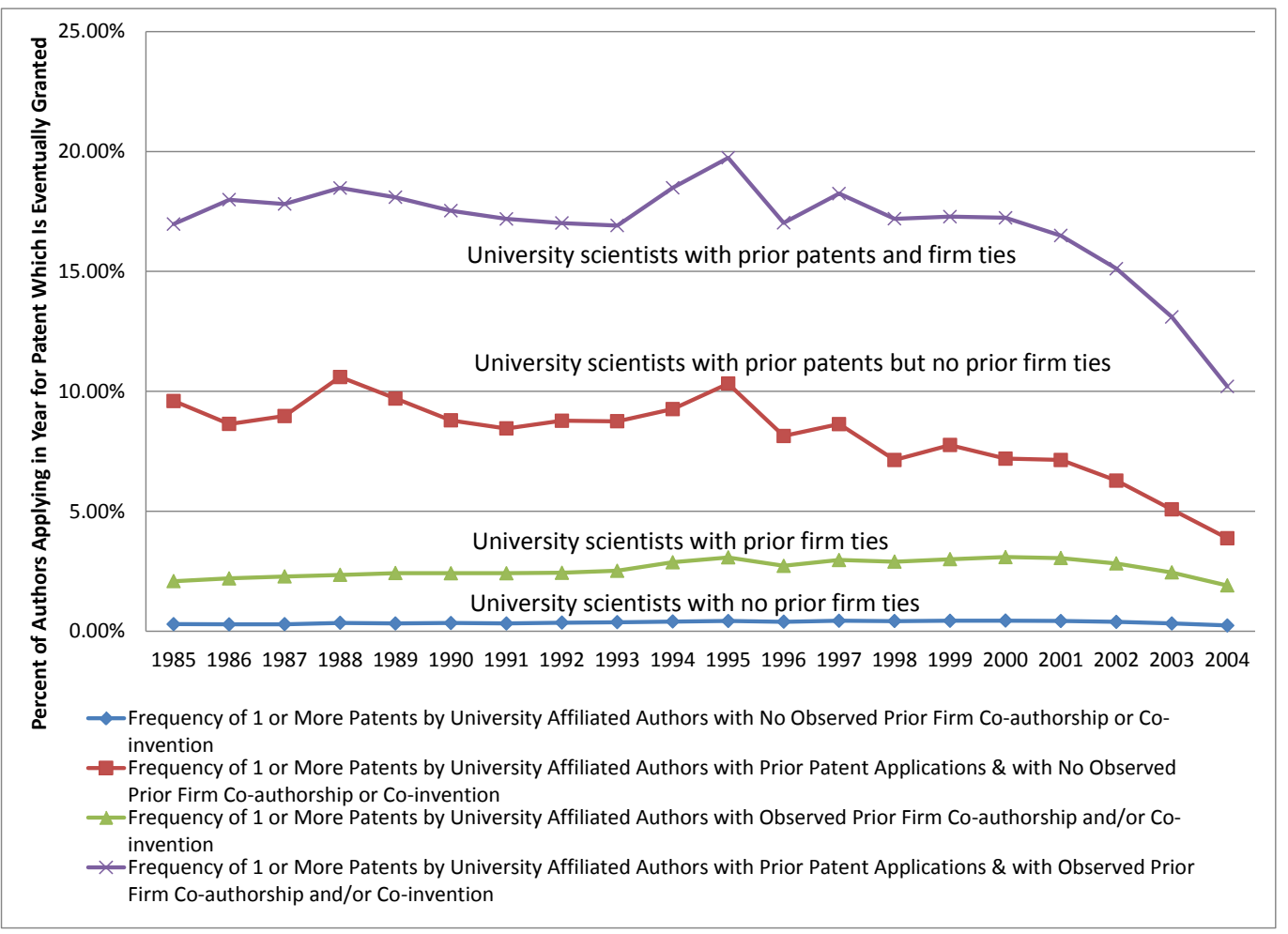




\section{$3 \quad$ Generality of Tacit Knowledge and Natural Excludability}

Figure 5 sketches the basic model. Knowledge tends to evolve from new, highly tacit to codified, and finally to taken for granted where it is once again highly tacit. Thus, we embed our understanding of tacit knowledge in dual literatures that seldom cross-reference each other: one on work contexts and, more specifically, on technology transfer from science to industry, and the other on culture and society, spanning organizations, professions and groups. Knowledge codification processes, including new vocabularies (terms, phrases), mathematical formulae, and machines, ${ }^{7}$ can be initiated for tacit knowledge at both ends, yielding the middle highly codified state.

Figure 5: Evolution of Knowledge: Covariation of Degrees of Codification and Institutionalization

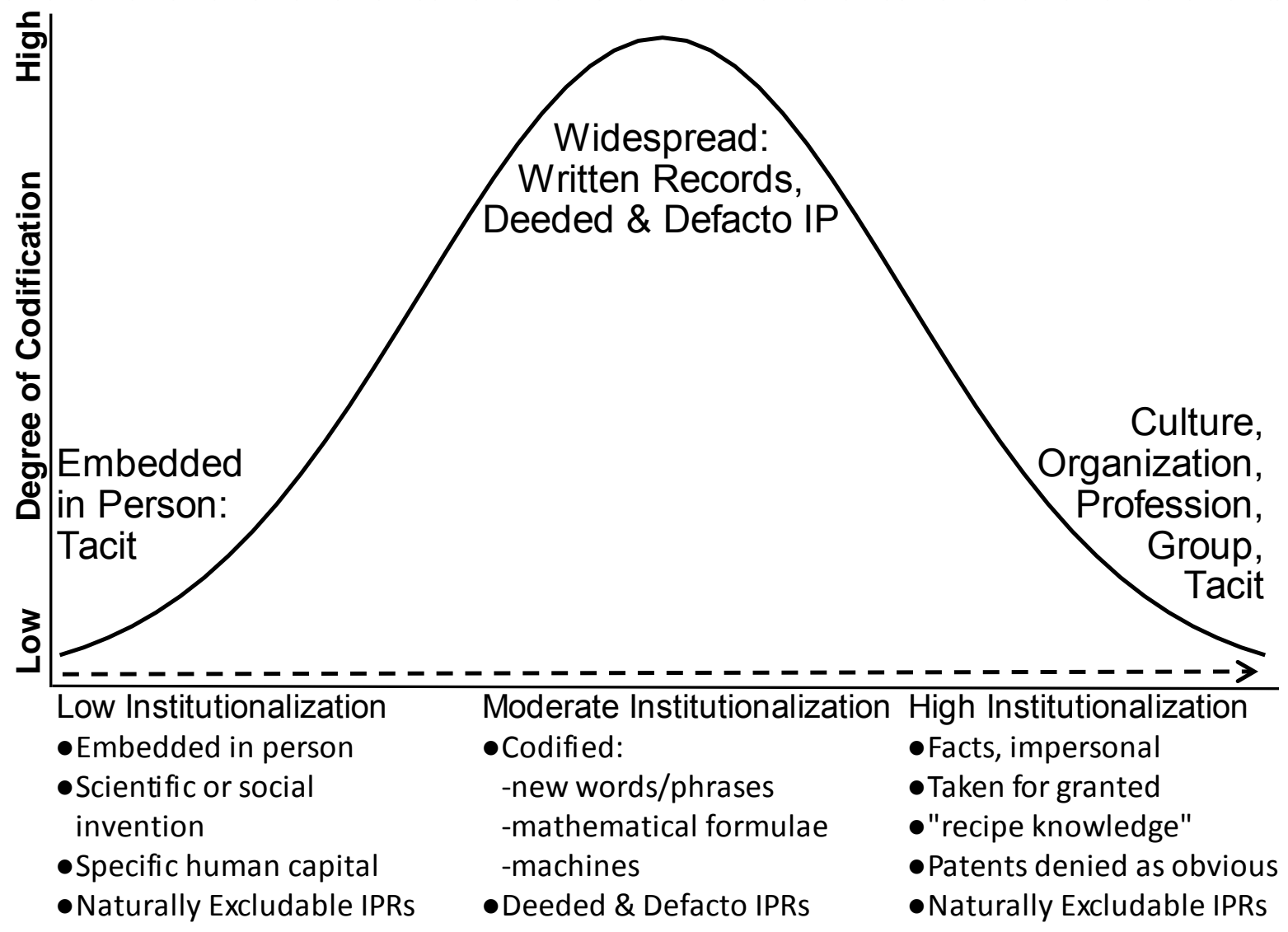

\footnotetext{
${ }^{7}$ Machines often encode part of the discovery, making use of the new methods routine and simple, allowing entry of non-discovering scientists and initiating a higher rate of diffusion commensurate with the value of the methods made routine (Baird 2004:Ch.6). Examples in biotechnology include gene splicing machines and in nanotechnology scanning probe microscopes, and later atomic force microscopes.
} 
Highly tacit knowledge dominates at both high and low degrees of institutionalization. Both are of interest for the research reported here. At one end of the continuum, there is a discovering scientist who, when the discovery is initially made, may be the only one who really understands fully what the discovery is, how it was produced and how to proceed in order to make the next related discovery ${ }^{8}$. At the other end is the team, sharing at least some of the tacit knowledge involved in the discovery, but bounded from other groups operating at that end such that explaining or sharing the discovery with them is not simple and perhaps not even possible, at least initially.

Tacit knowledge can be viewed as at least partially rivalrous and excludable information and thus "appropriable" as long as it remains difficult to learn it. Therefore, the scientists who hold this knowledge become the main resource around which firms are built or transformed (in biotechnology, see Zucker, Darby, and Brewer 1998, Zucker, Darby, and Armstrong 1998, 2002; in nanotechnology, see Darby and Zucker 2005). This has a number of important implications:

- Diffusion occurs slowly, from one of the discoverers to his/her research team. Tacit knowledge, not yet codified, is transmitted best at the lab bench. In biotechnology, from 1969 to the end of our data set in 1992, 81 percent of new authors reporting geneticsequence discoveries for the first time in articles recorded in GenBank were writing as co-authors with previously published discoverers (Zucker, Darby and Torero 2002, pp. 632-633). Some of this effect is due most likely to training postdoctoral students, but the percentage is too high for training new entrants to be the primary explanation.

- The discovery is not alienable from the scientists as long as it remains tacit. The tacit knowledge is part of their intellectual human capital. Due to the naturally excludable nature of tacit knowledge, this human capital earns supernormal returns to investment until the diffusion level drives the return to that knowledge down to the cost of learning it from others (Zucker, Darby and Torero 2002).

- Even if the university is assigned a patent to the discovery most of the value accrues to the discoverers since without their cooperation the patent cannot be used. Our fieldwork for biotechnology and more general studies by Jensen and Thursby (2001) and Thursby and Thursby (2002) support the natural excludability hypothesis. For example, in the Jensen and Thursby survey of Technology Transfer Office managers (2001, p. 243): "For 71 percent of the inventions licensed, respondents claim that successful commercialization requires cooperation by the inventor and licensee in further development.”

\footnotetext{
${ }^{8}$ This constitutes personal knowledge and excludes others (Polanyi 1962). If a person dies without communicating the knowledge, then it is lost. Similarly, knowledge is lost if a research line ends and all retire or die, as happened in Russia when physicists with knowledge of nuclear weapons construction retired (MacKenzie and Spinardi 1995).
} 


\section{Defacto and Deeded Intellectual Property: Two Definitions}

Before turning to some examples of the operation of informal, naturally excludable, intellectual property across emerging industries and all high technology industries, we will define and distinguish more clearly among types of intellectual property.

Deeded intellectual property rights are straightforward in their meaning: rights of control or exclusion stated in a deed that enumerates specific rights belonging to the holder of the deed. ${ }^{9}$ For a U.S. patent (from "letters patent"-in clear words) or registered copyright, ${ }^{10}$ the holder of the deed is the inventor(s) or creator(s) unless his or her rights have been re-granted, or "assigned," to another. In patents, if such an assignment has been made by the time the patent is issued - usually several years after the invention - the "assignee at issue" is listed as such on the patent front page, often but not necessarily the organization, or one of the organizations, where the inventor works.

Figure 6 summarizes the major types of intellectual property (IP) which provide protection from unlicensed use and hence incentive for innovation in the U.S. and many other advanced economies. Patents and registered copyrights provide formal rights to sue for damages and/or injunctive relief from unlicensed users of inventions and other forms of creation. These are the most important deeded IP for innovation. Registered trade and service marks can play a supplementary role in extending some protection with respect to some consumers after patent protection has expired. The scientific literature can be used to establish priority of invention, implicitly broaden claims while aiding required disclosure, and establish prior art in challenging a patent held by another firm (see Web of Science, maintained by Thomson Reuters -- as successor to the Institute for Scientific Information or ISI - and Google). Scientific articles can also serve purposes of disclosure (required for a valid patent) and, paradoxically, stake out broader claims with less full disclosure than might otherwise be allowed.

Deeded intellectual property rights are systematically measurable indicators of specific innovative activities by identifiable actors and have become central to empirical research on innovation. Unfortunately, a narrow focus on the readily measured deeded IPRs to the exclusion

\footnotetext{
${ }^{9}$ Deeds to land specify the boundaries and content, such as mineral rights, that are controlled by the owner. In the same way, a patent's "claims" section describes the boundaries and specific "claimed" content of the invention controlled by the owner of the patent. References to related prior patents are included to specify and exclude technologies that belong to the owners of the referenced patent(s) and excluded from any claims granted by this patent. It may be necessary for the owner to obtain a license from, ownership of, or expiration of the referenced patent(s) in order to practice the technology described in the patent.

${ }^{10}$ Unregistered copyrights operate like defacto IPRs discussed below, rather than deeded IPRs. It is possible to sue for infringement though no copyright notice is required, and does not have to be filed to be enforceable. Unregistered copyrights transfer only to heirs, and are valued by damage awards. Potential problems around the broad power of unregistered copyright are clear, and challenges likely.
} 
of other important protection from imitators brings to mind the proverbial drunk searching under the lamppost because the light is best there, even though the keys were dropped over in the dark. Other forms of intellectual property are rarely if ever recorded and serve as both substitutes and complements to the deeded forms of IP. We call these unrecorded forms "defacto" IP (for IP "in fact," if not in law).

\section{Figure 6: Defacto and Deeded Intellectual Property}

\begin{tabular}{|c|c|c|c|c|}
\hline Form of Protection & $\begin{array}{l}\text { Means of } \\
\text { Protection }\end{array}$ & \begin{tabular}{|l} 
Degree of \\
Disclosure
\end{tabular} & \begin{tabular}{|l} 
Transfer/ \\
Transmission
\end{tabular} & Value Measures \\
\hline Deeded IPRs & \multirow{3}{*}{$\begin{array}{l}\text { Suit for } \\
\text { infringement } \\
\text { Priority claims }\end{array}$} & \multirow{3}{*}{$\begin{array}{l}\text { Disclosure } \\
\text { required } \\
\text { Disclosure } \\
\text { required }\end{array}$} & \multirow{3}{*}{$\begin{array}{l}\text { Efficient transfer } \\
\text { of all or limited } \\
\text { Free / citation }\end{array}$} & \multirow{3}{*}{$\begin{array}{l}\text { Citations, claims, } \\
\text { firm success } \\
\text { Citations }\end{array}$} \\
\hline $\begin{array}{l}\text { Patents } \\
\text { • Non-patent references }\end{array}$ & & & & \\
\hline Scientific Literature & & & & \\
\hline $\begin{array}{l}\text { Copyrights \& } \\
\text { trademarks_registered }\end{array}$ & $\begin{array}{l}\text { Suit for } \\
\text { infringement }\end{array}$ & $\begin{array}{l}\text { Disclosure } \\
\text { required }\end{array}$ & $\begin{array}{l}\text { Efficient transfer of } \\
\text { all or limited rights }\end{array}$ & $\begin{array}{l}\text { Royalties, license } \\
\text { rev., firm success }\end{array}$ \\
\hline Defacto IPRs & \multirow[b]{2}{*}{$\begin{array}{l}\text { Suit: case \& } \\
\text { statute law } \\
\text { Only secrecy/no } \\
\text { legal protection }\end{array}$} & \multirow[b]{2}{*}{$\begin{array}{l}\text { No disclosure } \\
\text { No disclosure }\end{array}$} & \multirow[b]{2}{*}{$\begin{array}{l}\text { No transfer outside } \\
\text { firm } \\
\text { Only in firm }\end{array}$} & \multirow[b]{2}{*}{$\begin{array}{l}\text { Damage awards, } \\
\text { firm success } \\
\text { Firm success }\end{array}$} \\
\hline $\begin{array}{l}\text { Trade secrets \& non- } \\
\text { compete covenants } \\
\text { Actual secrecy }\end{array}$ & & & & \\
\hline $\begin{array}{l}\text { Breakthrough tacit } \\
\text { knowledge } \\
\text { - human capital } \\
\text { - boundaries: team, } \\
\text { organization, industry }\end{array}$ & $\begin{array}{l}\text { Natural } \\
\text { excludability } \\
\text { •information } \\
\text { envelopes along } \\
\text { team/group } \\
\text { boundaries }\end{array}$ & \begin{tabular}{|l|} 
Disclosure \\
naturally difficult \\
•work with others \\
•codify (new words, \\
formulae, machines)
\end{tabular} & \begin{tabular}{|l|} 
Transfer via teams \\
$\bullet$ People acquire \\
human capital \\
-Initial super-normal \\
returns
\end{tabular} & $\begin{array}{l}\text { Archives of } \\
\text { discoveries (e.g., } \\
\text { GenBank, } \\
\text { Nanobank.org) } \\
\text { Impact on tied } \\
\text { firms' success }\end{array}$ \\
\hline $\begin{array}{l}\text { Copyrights \& trade- } \\
\text { marks-unregistered }\end{array}$ & $\begin{array}{l}\text { Suit for } \\
\text { infringement }\end{array}$ & $\begin{array}{l}\text { No or private } \\
\text { disclosure }\end{array}$ & $\begin{array}{l}\text { Transfers only to } \\
\text { heirs }^{a}\end{array}$ & $\begin{array}{l}\text { Damage awards, } \\
\text { Firm success }\end{array}$ \\
\hline
\end{tabular}

anregistered copyrights only; unregistered trade and service marks can be transferred to others with moderate difficulty.

The first group of defacto IP is those associated with conscious strategies of and investments in secrecy and concealment. One strategy is to take the steps necessary to establish and maintain trade secrets which are enforceable in court although the need to do so may mean the end of their value to their creator. An alternative or complementary strategy is to use actual secrecy as with the Coca-Cola formula or much earlier obstetric forceps. Since the most effective use of these strategies means that there are no markers other than persistent firm success, empirical research in innovation is hard pressed to deal with these methods. Although the forceps and Coca-Cola secrets are known to have been maintained for a century or more, in industries in which lead times are long relative to the product cycle or the learning curve is very steep secrets need not remain so for more than a year or two to offer effective protection for innovation. Klevorick, Levin, Nelson, and Winter (1995, pp. 793-798) report survey results that secrecy, lead time, and learning curve are each regarded as more important than patents for most industries. Among the generally more high-tech oriented firms participating in the U.S. Commerce Department's Advanced Technology Program, patents were a primary intellectual property 
strategy for 61 percent compared to 51 percent for trade secrets, with about three quarters of the firms reporting use of patents and secrecy as either a primary or secondary strategy (Powell 1997). Cheung (1982) provides a rare analysis of the use of trade and actual secrecy. While discussing the Coca Cola formula and other successful uses of secrecy, Cheung was apparently not aware of obstetrical forceps which were closely held as a trade secret for over 150 years because English law did not permit patenting such life-saving inventions (Dunn 1999, U.K. Patent Office 2004).

The most important source of latent IP derives from the tacit knowledge that surrounds almost every scientific and technological breakthrough. ${ }^{11}$ Generally, only the discoverer or discovering team possesses the full knowledge of how to do what has been achieved for the first time. There is a great deal of tacit knowledge of exactly what all is involved in the procedures outlined in a scientific article or patent. Indeed what are necessary steps or environment is usually not known until much later when simplifications are tested as part of codification process. The small number per year of successful new learners in a single laboratory compounded by keeping the best on one of his or her mentor's teams, ${ }^{12}$ creates a slow spread of knowledge which can be tracked in a chain of mentors/mentees that can span decades (Zucker, Darby and Torero 2002). In Zucker, Darby, and Brewer (1998) we argued and provided initial evidence that this "natural excludability" of most breakthrough scientific and technological innovations made it difficult for imitative rivals to compete away the high returns of the discoverers and the early mentees and the firms that they found and guide. In Zucker, Darby and Armstrong (1998, 2002) and Zucker and Darby (2001) we showed that co-authorship of scientific articles was evidence of working together sufficient to transfer tacit knowledge.

Breakthrough tacit knowledge is embodied in and travels through people to impact positively on firms' success. The underlying mechanisms engendering impact, while shared to some degree between other forms of intellectual property rights, are inherently part of intellectual human capital, and require transmission from person to person. Note that the various types of rights are not exclusive but often combine. For example, we have discovered through interviews with scientists, firm executives, and firm and university intellectual property lawyers that it is fairly common to combine two or more types of rights to strengthen protection, and also common (but far from universal) to progress from defacto to deeded rights as codification occurs.

${ }^{11}$ There is one other type of IP which is not actively concealed (as a rule) but neither is it reported in any systematic way accessible for empirical research: it also remains latent, indicative of its unconscious or incidental hidden nature as opposed to active concealment. Thus, unregistered copyrights, trademarks, and service marks belonging to innovative firms are unregistered primarily because the additional protection afforded by registration is deemed not worth the cost except for a few specifically identified items for which deeded IPRs are obtained.

${ }^{12}$ For example, as late as the mid-1990s a distinguished university bioscientist who made a former student rich by hiring him for the biotech firm founded by the professor denounced a rival professor-entrepreneur who "tried to steal my best cloner." 


\section{Data}

The data are all derived from the on-line public libraries Nanobank.org and kauffman.org/comets/ which we and our team have created as a public resource or from the source data in the COMETSandSTARS database at UCLA for on-site use by qualified researchers with approval of the commercial licensors. The database is documented in Zucker, Darby and Fong (2014). This empirical analysis is limited to U.S. firms during the period of Nanobank data 1981-2004. We plan to extend Nanobank to at least 2012 as a component of COMETS and COMETSandSTARS databases, but those data are not yet completed.

Table 1: Summary Statistics for Full Sample

\begin{tabular}{|c|c|c|c|c|c|c|c|c|c|c|c|c|c|c|c|}
\hline Variable & $\mathrm{N}$ & Mean & Std. Dev. & Min & $\operatorname{Max}$ & $\mathrm{N}$ & Mean & Std. Dev. & Min & $\operatorname{Max}$ & $\mathrm{N}$ & Mean & Std. Dev. & Min & $\operatorname{Max}$ \\
\hline & \multicolumn{5}{|c|}{ Bio/Chem/Med } & \multicolumn{5}{|c|}{ Computing/IT } & \multicolumn{5}{|c|}{ Nanotechnology } \\
\hline $\begin{array}{l}\text { Articles authored by establishment's employees published in } \\
\text { given year, fractional amounts rounded up to next integer }\end{array}$ & 1168789 & 0.54588 & 14.7505 & 0 & 3041 & 395459 & 0.05263 & 1.4996 & 0 & 265 & 302486 & 0.21356 & 9.20422 & 0 & 2837 \\
\hline $\begin{array}{l}\text { Patents }{ }^{b} \text { assigned to the firm allocated to establishment by } \\
\text { residence of inventor(s), fractional amounts rounded up }\end{array}$ & 1168789 & 0.09635 & 1.33572 & 0 & 180 & 395459 & 0.39705 & 6.71935 & 0 & 920 & 302486 & 0.33801 & 4.61735 & 0 & 1648 \\
\hline Establishment's articles knowledge stock ${ }^{a}$ & 1168789 & 2.18092 & 59.4841 & 0 & 12847.1 & 395459 & 0.18793 & 6.33863 & 0 & 766.198 & 302486 & 0.84837 & 35.7517 & 0 & 6017.4 \\
\hline Establishment's patents knowledge stock ${ }^{\mathrm{a}, \mathrm{b}}$ & 1168789 & 0.40482 & 5.01742 & 0 & 505.393 & 395459 & 1.60627 & 24.2348 & 0 & 2752.1 & 302486 & 1.33773 & 13.3912 & 0 & 1683.43 \\
\hline $\begin{array}{l}\text { Venture capital investments received by the establishment in } \\
\text { the yearc }\end{array}$ & 1168789 & 1.90308 & 118.872 & 0 & 58975.1 & 395459 & 5.68451 & 198.657 & 0 & 58975.1 & 302486 & 5.82454 & 207.918 & 0 & 58975.1 \\
\hline SBIR grants to establishment in the year ${ }^{c}$ & 1168789 & 72.5648 & 2095.27 & 0 & 403534 & 395459 & 4.01507 & 266.548 & 0 & 78196.2 & 302486 & 1.33336 & 138.416 & 0 & 26138.7 \\
\hline $\begin{array}{l}\text { Non-patent reference dummy ( }=1 \text { if establishment has at least } \\
\text { one patent with non-patent references in given year) }\end{array}$ & 1168789 & 0.04363 & 0.20428 & 0 & 1 & 395459 & 0.06216 & 0.24145 & 0 & 1 & 302486 & 0.11237 & 0.31582 & 0 & 1 \\
\hline $\begin{array}{l}\text { Star scientist article authorships as or with establishment } \\
\text { employee(s), total for given year }\end{array}$ & 1168789 & 0.06269 & 2.82433 & 0 & 713 & 395459 & 0.01969 & 1.03496 & 0 & 148.833 & 302486 & 0.02602 & 1.68879 & 0 & 332 \\
\hline \multirow[t]{2}{*}{$\begin{array}{l}\text { University co-authorship dummy (=1 if establishment has had } \\
\text { any university co-author(s) up through current year) }\end{array}$} & 1168789 & 0.14821 & 0.3553 & 0 & 1 & 395459 & 0.06555 & 0.2475 & 0 & 1 & 302486 & 0.05756 & 0.2329 & 0 & 1 \\
\hline & \multicolumn{5}{|c|}{ Semiconductors/Integrated Circuits } & \multicolumn{5}{|c|}{ Other Engineering } & \multicolumn{5}{|c|}{ Other Science } \\
\hline $\begin{array}{l}\text { Articles authored by establishment's employees published in } \\
\text { given year, fractional amounts rounded up to next integer }\end{array}$ & 420510 & 0.39831 & 22.8292 & 0 & 8379 & 2397030 & 0.00832 & 0.32933 & 0 & 195 & 547287 & 0.19405 & 5.20568 & 0 & 1320 \\
\hline $\begin{array}{l}\text { Patents }{ }^{\mathrm{b}} \text { assigned to the firm allocated to establishment by } \\
\text { residence of inventor(s), fractional amounts rounded up }\end{array}$ & 420510 & 0.09137 & 3.69837 & 0 & 909 & 2397030 & 0.1685 & 2.77186 & 0 & 700 & 547287 & 0.107 & 1.27363 & 0 & 257 \\
\hline Establishment's articles knowledge stock ${ }^{a}$ & 420510 & 1.80553 & 92.8593 & 0 & 18416.4 & 2397030 & 0.02665 & 1.15271 & 0 & 317.882 & 547287 & 0.80759 & 18.1278 & 0 & 2053.71 \\
\hline Establishment's patents knowledge stock ${ }^{\mathrm{a}, \mathrm{b}}$ & 420510 & 0.35836 & 13.3851 & 0 & 2710.41 & 2397030 & 0.70276 & 10.5259 & 0 & 2073.97 & 547287 & 0.41959 & 4.29175 & 0 & 611.599 \\
\hline $\begin{array}{l}\text { Venture capital investments received by the establishment in } \\
\text { the year }{ }^{c}\end{array}$ & 420510 & 2.64697 & 106.59 & 0 & 29627.4 & 2397030 & 1.4952 & 93.9787 & 0 & 58975.1 & 547287 & 2.81199 & 158.212 & 0 & 58975.1 \\
\hline SBIR grants to establishment in the year ${ }^{c}$ & 420510 & 16.2899 & 732.795 & 0 & 144742 & 2397030 & 1.30344 & 177.563 & 0 & 114295 & 547287 & 19.5837 & 644.891 & 0 & 92047.8 \\
\hline $\begin{array}{l}\text { Non-patent reference dummy ( }=1 \text { if establishment has at least } \\
\text { one patent with non-patent references in given year) }\end{array}$ & 420510 & 0.01416 & 0.11814 & 0 & 1 & 2397030 & 0.03928 & 0.19427 & 0 & 1 & 547287 & 0.04076 & 0.19774 & 0 & 1 \\
\hline $\begin{array}{l}\text { Star scientist article authorships as or with establishment } \\
\text { employee(s), total for given year }\end{array}$ & 420510 & 0.05119 & 3.20099 & 0 & 739.5 & 2397030 & 0.00203 & 0.2393 & 0 & 205 & 547287 & 0.015 & 0.34888 & 0 & 52 \\
\hline $\begin{array}{l}\text { University co-authorship dummy (=1 if establishment has had } \\
\text { any university co-author(s) up through current year) }\end{array}$ & 420510 & 0.14471 & 0.35181 & 0 & 1 & 2397030 & 0.01443 & 0.11924 & 0 & 1 & 547287 & 0.07918 & 0.27002 & 0 & 1 \\
\hline
\end{tabular}

Notes: a. Knowledge stocks are calculated by adding the two-year-window-citations-weighted count of articles or patents to 0.8 times the previous year's knowledge stock value (reduced by a conventional $20 \% /$ year depreciation rate).

b. Patents refer to all patents that were granted by the end of 2005 which were applied for in the current year.

c. The amounts of venture capital investment and SBIR grants received are measured as 3-year moving averages dated by the last of the 3 years. After lagging this is the average amount over the 3 years prior to the current year.

The analysis is based on concepts of region and science and technology (S\&T) areas that are conveniently coded in the databases above. The U.S. Bureau of Economic Analysis defines 179 functional economic areas such that each U.S. county is assigned to a region which includes 
the major metropolitan center for which commuting, shopping, and newspaper readership predominate (Johnson and Kort 2004). These "BEA areas” are used to define the local regions in which firms operate. We use "establishment" to refer to the operations of a given firm in a given region. A firm can have 1 or more establishments. The analysis data set comprises a panel of observations for establishments and year. Summary statistics for the full sample are reported in Table 1 and Table 2 reports these statistics for the sample restricted to private firms. ${ }^{13}$

Table 2: Summary Statistics for Private-Firms Sample

\begin{tabular}{|c|c|c|c|c|c|c|c|c|c|c|c|c|c|c|c|}
\hline Variable & $\mathrm{N}$ & Mean & Std. Dev. & Min & $\operatorname{Max}$ & $\mathrm{N}$ & Mean & Std. Dev. & Min & $\operatorname{Max}$ & $\mathrm{N}$ & Mean & Std. Dev. & Min & $\operatorname{Max}$ \\
\hline & \multicolumn{5}{|c|}{ Bio/Chem/Med } & \multicolumn{5}{|c|}{ Computing/IT } & \multicolumn{5}{|c|}{ Nanotechnology } \\
\hline $\begin{array}{l}\text { Initial Public Offering (IPO) dummy (=1 in year firm makes its } \\
\text { initial public offering) }\end{array}$ & 1133155 & 0.00144 & 0.03797 & 0 & 1 & 369088 & 0.00272 & 0.05208 & 0 & 1 & 278960 & 0.00344 & 0.05859 & 0 & 1 \\
\hline Establishment's articles knowledge stock ${ }^{a}$ & 1133155 & 1.90962 & 56.0801 & 0 & 12847.1 & 369088 & 0.17642 & 5.6469 & 0 & 766.198 & 278960 & 0.78418 & 33.0146 & 0 & 6017.4 \\
\hline Establishment's patents knowledge stock ${ }^{\mathrm{a}, \mathrm{b}}$ & 1133155 & 0.38154 & 4.86786 & 0 & 505.393 & 369088 & 1.27015 & 19.5106 & 0 & 2542.73 & 278960 & 1.26438 & 12.5707 & 0 & 1683.43 \\
\hline $\begin{array}{l}\text { Venture capital investments received by the establishment in } \\
\text { the year }{ }^{c}\end{array}$ & 1133155 & 1.60136 & 93.0615 & 0 & 53158.6 & 369088 & 5.02144 & 156.265 & 0 & 53158.6 & 278960 & 5.02779 & 153.018 & 0 & 53158.6 \\
\hline SBIR grants to establishment in the year ${ }^{c}$ & 1133155 & 66.1993 & 2025.27 & 0 & 403534 & 369088 & 4.28736 & 275.868 & 0 & 78196.2 & 278960 & 1.42961 & 144.049 & 0 & 26138.7 \\
\hline $\begin{array}{l}\text { Non-patent reference dummy ( }=1 \text { if establishment has at least } \\
\text { one patent with non-patent references in given year) }\end{array}$ & 1133155 & 0.04112 & 0.19858 & 0 & 1 & 369088 & 0.05652 & 0.23092 & 0 & 1 & 278960 & 0.10753 & 0.30978 & 0 & 1 \\
\hline $\begin{array}{l}\text { Star scientist article authorships as or with establishment } \\
\text { employee(s), total for given year }\end{array}$ & 1133155 & 0.05709 & 2.82383 & 0 & 713 & 369088 & 0.01814 & 0.94618 & 0 & 148.833 & 278960 & 0.0235 & 1.56566 & 0 & 332 \\
\hline \multirow[t]{2}{*}{ any university co-author(s) up through current year) } & 1133155 & 0.14734 & 0.35445 & 0 & 1 & 369088 & 0.06612 & 0.24849 & 0 & 1 & 278960 & 0.05762 & 0.23303 & 0 & 1 \\
\hline & \multicolumn{5}{|c|}{ Semiconductors/Integrated Circuits } & \multicolumn{5}{|c|}{ Other Engineering } & \multicolumn{5}{|c|}{ Other Science } \\
\hline $\begin{array}{l}\text { Initial Public Offering (IPO) dummy (=1 in year firm makes its } \\
\text { initial public offering) }\end{array}$ & 407178 & 0.00135 & 0.03669 & 0 & 1 & 2342042 & 0.00103 & 0.03204 & 0 & 1 & 527193 & 0.00162 & 0.04026 & 0 & 1 \\
\hline Establishment's articles knowledge stock ${ }^{a}$ & 407178 & 1.72972 & 91.0056 & 0 & 18416.4 & 2342042 & 0.02659 & 1.14424 & 0 & 317.882 & 527193 & 0.62072 & 13.1774 & 0 & 1476.83 \\
\hline Establishment's patents knowledge stock ${ }^{\mathrm{a}, \mathrm{b}}$ & 407178 & 0.27593 & 8.0374 & 0 & 1076.99 & 2342042 & 0.65535 & 9.89743 & 0 & 2073.97 & 527193 & 0.39405 & 3.77162 & 0 & 452.721 \\
\hline $\begin{array}{l}\text { Venture capital investments received by the establishment in } \\
\text { the year }{ }^{c}\end{array}$ & 407178 & 2.29071 & 101.169 & 0 & 29627.4 & 2342042 & 1.27209 & 73.199 & 0 & 53158.6 & 527193 & 2.28794 & 115.293 & 0 & 53158.6 \\
\hline SBIR grants to establishment in the year ${ }^{c}$ & 407178 & 15.4707 & 717.332 & 0 & 144742 & 2342042 & 1.29346 & 178.862 & 0 & 114295 & 527193 & 18.4797 & 625.336 & 0 & 92047.8 \\
\hline $\begin{array}{l}\text { Non-patent reference dummy ( }=1 \text { if establishment has at least } \\
\text { one patent with non-patent references in given year) }\end{array}$ & 407178 & 0.01234 & 0.11041 & 0 & 1 & 2342042 & 0.03786 & 0.19086 & 0 & 1 & 527193 & 0.03923 & 0.19413 & 0 & 1 \\
\hline $\begin{array}{l}\text { Star scientist article authorships as or with establishment } \\
\text { employee(s), total for given year }\end{array}$ & 407178 & 0.04941 & 3.19422 & 0 & 739.5 & 2342042 & 0.00204 & 0.24152 & 0 & 205 & 527193 & 0.01286 & 0.30889 & 0 & 52 \\
\hline $\begin{array}{l}\text { University co-authorship dummy ( }=1 \text { if establishment has had } \\
\text { any university co-author(s) up through current year) }\end{array}$ & 407178 & 0.14268 & 0.34975 & 0 & 1 & 2342042 & 0.0144 & 0.11913 & 0 & 1 & 527193 & 0.07786 & 0.26795 & 0 & 1 \\
\hline
\end{tabular}

Notes: a. Knowledge stocks are calculated by adding the two-year-window-citations-weighted count of articles or patents to 0.8 times the previous year's knowledge stock value (reduced by a conventional $20 \% /$ year depreciation rate). current year.

b. Patents refer to all patents that were granted by the end of 2005 which were applied for in the

c. The amounts of venture capital investment and SBIR grants received are measured as 3-year moving averages dated by the last of the 3 years. After lagging this is the average amount over the 3 years prior to the current year.

Darby and Zucker (1999) attempt to specify a set of seven area clusters which can be used to compare activity in journal articles (Institute for Scientific Information 1981-1997), university doctoral programs (National Research Council 1995), and patents (Zucker and Darby 1999). These seven clusters are used here with two exceptions: First, the humanities and the social sciences are dropped for this study because they have little specific applicability to particular high technology industries. Second, we subtract those articles and patents identified for NanoBank.org from the area in which they would have been previously classified. Thus, we obtain 6 S\&T areas: Biotechnology/Chemistry/Medicine, Computing/Information Technology,

${ }^{13}$ Corresponding tables of correlations for these variables are in Appendix Tables A1 and A2. 
Nanotechnology, Semiconductors/Integrated Circuits/Superconductors, Other Engineering, and Other Sciences. A given establishment is assigned to the one or more S\&T areas in which it has patented, published, and/or received Small Business Innovation Research (SBIR) grants.

Articles are counted by pro-rating among the reported research addresses in the ThomsonReuters Web of Science ${ }^{\mathrm{TM}}$ (WoS) database. Patents from COMETS are located in regions in proportion to the residences of the inventor(s) and attributed to the firm assignee's establishments in the same regions. As a quality control, patents are counted weighed by their citations by other patents in the year granted and the next year. Articles are counted weighed by their WoS citations in the year of publication and the next year. When used as regressands in poisson regressions any fractional counts for articles or patents are rounded up to the next integer. We also create knowledge stocks for citation-weighted articles or patents, with the prior year's knowledge stock depreciated by a conventional 20 percent and added to this year's citation-weighted count of articles or patents, respectively.

Star scientists are defined at the 5,401 stars as identified in ISIHighlyCited.com ${ }^{\text {SM }}$; see Zucker and Darby (2014) in this issue for a detailed discussion and validation of this definition of stars. The COMETSandSTARS articles data were queried to count the number of star scientists on each WoS article in a given year which includes the establishment's address as an author's address. The sum of these counts over all the establishment's articles for the year gives the total number of times stars appear in the year as or with the establishment's employees, also known as its star article ties for the year. These counts provide a gauge of the extent of star involvement and breakthrough tacit knowledge transfer that has proven valuable in predicting firm success measures such as new products, employment growth and patents (Zucker, Darby and Armstrong 1998, 2002; Zucker and Darby 2001).

The COMETSandSTARS articles data also were queried to determine whether or not each establishment has ever through a given year had an author on an article which also had a university author. This provides an indicator that the establishment is both open to university collaborations and has scientists capable of engaging in them and thus receiving tacit knowledge flows.

Data on venture capital investments in firms was obtained from the VentureXpert database, currently available from ThomsonReuters. SBIR grants to firms will soon be available on-line from COMETS. SBIR grants received by a firm are prorated over the term of the grant and among the firm's known establishments.

The establishments in the analysis data set are those which appeared at least once through authorship, patenting, venture capital investments, or SBIR grants. For the purpose of identifying firms, articles and patents are not weighted so that even 0-citation documents count. Firms are classed as private until they are traded a U.S. exchange NASDAQ or listed as trading over the counter. Initial public offerings are identified using four primary sources: Compustat, EdgarPro Online, SDC's Global New Issues database, and VentureXpert. These sources mostly agreed on whether and when (at least to the year) initial public offerings occurred, but in numerous cases a process of hand-coded reconciliation across the sources was used. 


\section{Empirical Results}

In this section we report empirical evidence on the determinants of patenting and article publication by high-tech firm establishments, on the amounts of venture capital investments which they receive, and on the timing of their initial public offering if any. Our estimates are made using STATA 13 and standard methods so we will describe them with the results.

\subsection{Citation-Weighted Articles}

We report our estimates for publication of citation-weighted articles by U.S. high-techfirm establishments in Table 3. Since the publication of a WoS article by a firm establishment is generally a rare event, particularly one that gains any WoS citations in the first two year, it is appropriate to use poisson regression or one of its variants for estimation. To deal with concerns

Table 3: Citation-Weighted Articles by Author(s) from Firm Establishments Poisson Regressions with Establishment Fixed Effects and Robust Standard Errors, Explanatory Variables Lagged One Year, 1982-2005

\begin{tabular}{|c|c|c|c|c|c|c|}
\hline & \multicolumn{6}{|c|}{ Science and Technology Areas ${ }^{d}$} \\
\hline & $\begin{array}{l}\text { Bio/Chem/ } \\
\text { Med }\end{array}$ & $\begin{array}{l}\text { Computing/ } \\
\text { IT }\end{array}$ & $\begin{array}{l}\text { Nanotech- } \\
\text { nology }\end{array}$ & $\begin{array}{l}\text { Semicon- } \\
\text { ductors }\end{array}$ & $\begin{array}{c}\text { Other } \\
\text { Engineer }\end{array}$ & $\begin{array}{l}\text { Other } \\
\text { Science }\end{array}$ \\
\hline \multirow{2}{*}{ Establishment's patents knowledge stock, lagged $(100 \mathrm{~s})^{\mathrm{a}, \mathrm{b}}$} & $.7208368^{* * *}$ & $.0925841^{* * *}$ & $.286888^{* * *}$ & $.1901242^{* * *}$ & $.1579324 *$ & $.7861727^{* * *}$ \\
\hline & .1128276 & .0117844 & .0201648 & .0319263 & .0686619 & .2227446 \\
\hline \multirow{2}{*}{$\begin{array}{l}\text { Non-patent reference dummy ( }=1 \text { if establishment has at least } \\
\text { one patent with non-patent references in given year), lagged }\end{array}$} & $1.374333^{* * *}$ & $1.554737^{* * *}$ & $1.904267^{* * *}$ & $1.940444^{* * *}$ & $1.607936^{* * *}$ & $.6329722^{* * *}$ \\
\hline & .1483959 & .1452128 & .1940606 & .1527981 & .1326894 & .1868967 \\
\hline \multirow{2}{*}{$\begin{array}{l}\text { Star scientist article authorships as or with establishment } \\
\text { employee(s), total for given year, lagged }\end{array}$} & $.0164871^{* * *}$ & $.0330628^{* * *}$ & $.0048895^{*}$ & $.0071558^{* * *}$ & .0334954 & $.0580093^{* * *}$ \\
\hline & .0030353 & .0079796 & .0022549 & .0017094 & .0189453 & .0127019 \\
\hline \multirow{2}{*}{$\begin{array}{l}\text { University co-authorship dummy (=1 if establishment has had } \\
\text { any university co-author(s) up through current year), lagged }\end{array}$} & $3.053254 * * *$ & $2.369402^{* * *}$ & $2.894191^{* * *}$ & $2.804677^{* * *}$ & $2.230643^{* * *}$ & $2.850911^{* * *}$ \\
\hline & .114121 & .1698955 & .2689982 & .2469785 & .152021 & .2070509 \\
\hline \multirow{2}{*}{$\begin{array}{l}\text { Venture capital investments received by the establishment in } \\
\text { the year, lagged }{ }^{c}\end{array}$} & $4.876896 * *$ & .8754935 & 2.783606 & .2233361 & -6.286624 & 7.891539 \\
\hline & 1.588386 & .4560725 & 1.751318 & .3429298 & 4.438809 & 5.230701 \\
\hline \multirow{2}{*}{ SBIR grants to establishment in the year, lagged ${ }^{c}$} & .1277703 & .0585618 & .3133427 & .0385488 & $.245167 * * *$ & .0329437 \\
\hline & .0655934 & .1850351 & .4563854 & .0671055 & .0472805 & .2166767 \\
\hline \multirow{2}{*}{$\begin{array}{l}\chi^{2}(11) \text { for all coefficients }{ }^{d}=0 \\
\text { number of observations }\end{array}$} & $2879.23 * * *$ & $2435.16^{* * *}$ & $3079.63 * * *$ & $5666.23 * * *$ & $1024.56 * * *$ & $596.77^{* * *}$ \\
\hline & 365146 & 76830 & 73668 & 121965 & 225672 & 103322 \\
\hline
\end{tabular}

Notes: The estimated coefficients are reported above their italicized standard errors.

*Significantly different from 0 at the 5 -percent level. ${ }^{* *}$ Significant at the 1 -percent level. ${ }^{* * *}$ Significant at the 0.1 -percent level.

Estimates are for poisson regressions with firm fixed effects (unreported constants for each establishment) and with robust standard errors. The regressands are two-year-window-citationsweighted-counts of articles with author(s) giving the establishment's address in the article. Observations for establishments with all 0 dependent variables are dropped due to the establishment-specific constants.

a. Knowledge stocks are calculated by adding the two-year-window-citations-weighted count of articles or patents to 0.8 times the previous year's knowledge stock value (reduced by a conventional $20 \% /$ year depreciation rate).

b. Patents refer to all patents that were granted by the end of 2005 which were applied for in the current year. 
c. The amounts of venture capital investment and SBIR grants received are measured as 3-year moving averages dated by the last of the 3 years. After lagging this is the average amount over the 3 years prior to the current year.

d. All regressions also include the control variables (coefficients not reported here but available from first author): entry dummy (1 in year firm enters, otherwise 0), establishment age, year dummies for 2003, 2004, 2005 (controls for patents applied for but not granted by the end of 2005).

of reverse causation and limit the effects of any omitted establishment-specific variables, we lag all the explanatory variables by one year and estimate with establishment fixed effects and robust standard errors. ${ }^{14}$ We also exclude the articles knowledge stock as reflecting past history of what is being predicted. Two measures of scientific strength of the establishment - the patenting knowledge stock and star scientists' involvement - are robustly positive and significant across all $6 \mathrm{~S} \& \mathrm{~T}$ areas with the exception of the star variable for Other Engineering. We interpret the similar robustly positive and significant coefficients on appearance of non-patent references in the establishment's patents and a demonstrated openness to and capability of collaboration with university scientists as indicators that movement toward the university campus institutional model indeed predicts publishing more cited articles. We estimate generally positive coefficients for the two resource variables - venture capital and SBIR grants received - but only two of these reach conventional statistical significance.

\subsection{Citation-Weighted Patents}

Table 4: Citation-Weighted Patents ${ }^{\mathrm{b}}$ Assigned to Firm Establishments Poisson Regressions with Establishment Fixed Effects and Robust Standard Errors, Explanatory Variables Lagged One Year, 1982-2005

\begin{tabular}{|c|c|c|c|c|c|c|}
\hline & \multicolumn{6}{|c|}{ Science and Technology Areas ${ }^{d}$} \\
\hline & $\begin{array}{l}\text { Bio/Chem/ } \\
\text { Med }\end{array}$ & $\begin{array}{c}\text { Computing/ } \\
\text { IT }\end{array}$ & $\begin{array}{l}\text { Nanotech- } \\
\text { nology }\end{array}$ & $\begin{array}{c}\text { Semicon- } \\
\text { ductors }\end{array}$ & $\begin{array}{c}\text { Other } \\
\text { Engineer }\end{array}$ & $\begin{array}{l}\text { Other } \\
\text { Science }\end{array}$ \\
\hline \multirow{2}{*}{$\begin{array}{l}\text { Non-patent reference dummy ( }=1 \text { if establishment has at least } \\
\text { one patent with non-patent references in given year), lagged }\end{array}$} & $2.145971^{* * *}$ & $2.026566^{* * *}$ & $2.017214^{* * *}$ & $2.214439 * * *$ & $2.185659 * * *$ & $1.988473 * * *$ \\
\hline & .0557949 & .0759988 & .0721611 & .1682417 & .0465835 & .0730789 \\
\hline \multirow{2}{*}{ Establishment's articles knowledge stock, lagged $(100 \mathrm{~s})^{a}$} & $.0364327^{* * *}$ & $.1784149 * *$ & .0787028 & .0130419 & $.5266582^{* * *}$ & $.080194 *$ \\
\hline & .009083 & .0568221 & .0646492 & .0080444 & .1648779 & .0333044 \\
\hline \multirow{2}{*}{$\begin{array}{l}\text { Star scientist article authorships as or with establishment } \\
\text { employee(s), total for given year, lagged }\end{array}$} & $.0085895^{*}$ & $.0119251^{* *}$ & -.0059494 & .0024738 & .0003259 & $.0326701 * * *$ \\
\hline & .0041549 & .0040074 & .005504 & .0016117 & .011292 & .0079272 \\
\hline \multirow{2}{*}{$\begin{array}{l}\text { University co-authorship dummy (=1 if establishment has had } \\
\text { any university co-author(s) up through current year), lagged }\end{array}$} & $1.462465 * * *$ & $1.498488^{* * *}$ & $1.279137^{* * *}$ & $1.241165^{* * *}$ & $1.49489 * * *$ & $1.286905^{* * *}$ \\
\hline & .0979715 & .171059 & .1372278 & .2128964 & .1061274 & .1351003 \\
\hline \multirow{2}{*}{$\begin{array}{l}\text { Venture capital investments received by the establishment in } \\
\text { the year, lagged }{ }^{c}\end{array}$} & .3035151 & $1.285794 * *$ & .1342892 & .8321855 & $.3421736^{* * *}$ & $1.102021^{* * *}$ \\
\hline & .2162089 & .4202594 & .455976 & .4797107 & .0893817 & .3062012 \\
\hline \multirow{2}{*}{ SBIR grants to establishment in the year, lagged ${ }^{c}$} & $.1086235^{*}$ & -2.531859 & $-124.198 * * *$ & .1202505 & .3738076 & .131338 \\
\hline & .0477867 & 1.401882 & 4.249774 & .0974629 & .2153069 & .12164 \\
\hline$\chi^{2}(11)$ for all coefficients ${ }^{d}=0$ & $3569.74 * * *$ & $2148.65 * * *$ & $33300.18^{* * *}$ & $1253.62^{* * *}$ & $4106.87 * * *$ & $4293.32 * * *$ \\
\hline number of observations & 299369 & 119665 & 139256 & 46659 & 863648 & 150283 \\
\hline
\end{tabular}

${ }^{14}$ For these estimates and those in Table 4 using the same methodology, STATA drops observations for establishments with all 0 dependent variables since the establishment fixed effect constants fit them perfectly. 
Notes: The estimated coefficients are reported above their italicized standard errors.

*Significantly different from 0 at the 5-percent level. ${ }^{* *}$ Significant at the 1-percent level. ***Significant at the 0.1 -percent level.

Estimates are for poisson regressions with firm fixed effects (unreported constants for each establishment) and with robust standard errors. The regressands are two-year-window-citationsweighted-counts of patents ${ }^{b}$ assigned to the establishment's firm with inventor(s) in the same region as the establishment. Observations for establishments with all 0 dependent variables are dropped due to the establishment-specific constants.

All firms with no US patents at any location over the entire period are dropped before estimation.

a. Knowledge stocks are calculated by adding the two-year-window-citations-weighted count of articles or patents to 0.8 times the previous year's knowledge stock value (reduced by a conventional $20 \% /$ year depreciation rate).

b. Patents refer to all patents that were granted by the end of 2005 which were applied for in the current year.

c. The amounts of venture capital investment and SBIR grants received are measured as 3-year moving averages dated by the last of the 3 years. After lagging this is the average amount over the 3 years prior to the current year.

d. All regressions also include the control variables (coefficients not reported here but available from first author): entry dummy (1 in year firm enters, otherwise 0), establishment age, year dummies for 2003, 2004, 2005 (controls for patents applied for but not granted by the end of 2005).

Surprisingly to us, the same two campus-model indicators - non-patent reference on any of establishment's patents and history of establishment-university collaboration - were the only variables with uniformly significant effects for all 6 S\&T areas. The science-base variables of articles knowledge stock and star scientists publishing as or with establishment employees were significant for both Bio/Chem/Med and Computing/IT and either Other Engineering or Other Science, respectively. The amount of venture capital was significantly positive for three S\&T areas while SBIR grants were significantly positive for one area but significantly negative for another.

\subsection{Venture Capital Investments in Private Firms}

Given the prominent role of venture capital in the U.S. national innovation system, we investigate what sorts of firms are most likely to receive investments from venture capital firms as reported in Table 5. If venture capitalists in this period had a checklist of criteria, they seemed to apply pretty equally across high-tech areas: an impressive patenting track record and the corporate-academic model as evidenced by non-patent references on those patents and collaborations with university scientists on articles. The coefficients for all three of those variables were universally significantly positive. Venture capitalists also seemed to like to invest in firms that received SBIR grants (5 significantly positive coefficients), but were not too much impressed with star ties (2 significantly positive coefficients). Of the five statistically significant coefficients for the articles knowledge stock, only the one for other science was positive. Apparently, venture capitalists view articles written by firm scientists as a labor cost unless they are with university scientists and/or produce sufficient patents. 
Table 5. Amount of Venture Capital Investments Received ${ }^{\mathrm{C}}$ by Private Firm Establishments Tobit Analysis with Robust Standard Errors, Explanatory Variables Lagged One Year, 1982-2005

\begin{tabular}{|c|c|c|c|c|c|c|}
\hline & \multicolumn{6}{|c|}{ Science and Technology Areas ${ }^{d}$} \\
\hline & $\begin{array}{l}\text { Bio/Chem/ } \\
\text { Med }\end{array}$ & $\begin{array}{c}\text { Computing/ } \\
\text { IT }\end{array}$ & $\begin{array}{c}\text { Nanotech- } \\
\text { nology }\end{array}$ & $\begin{array}{c}\text { Semicon- } \\
\text { ductors }\end{array}$ & $\begin{array}{l}\text { Other } \\
\text { Engineer }\end{array}$ & $\begin{array}{l}\text { Other } \\
\text { Science }\end{array}$ \\
\hline Establishment's patents knowledge stock, lagged $(100 \mathrm{~s})^{a, b}$ & $\begin{array}{c}1159.668^{* * *} \\
167.3303\end{array}$ & $\begin{array}{l}273.3726^{* * *} \\
48.62003\end{array}$ & $\begin{array}{l}502.7913^{* * *} \\
119.4875\end{array}$ & $\begin{array}{l}465.9771^{* * *} \\
85.71425\end{array}$ & $\begin{array}{c}326.9395^{* * *} \\
38.34007\end{array}$ & $\begin{array}{c}1345.523^{* * *} \\
325.8384\end{array}$ \\
\hline $\begin{array}{l}\text { Non-patent reference dummy ( }=1 \text { if establishment has at least } \\
\text { one patent with non-patent references in given year), lagged }\end{array}$ & $\begin{array}{l}1050.003^{* * *} \\
149.242\end{array}$ & $\begin{array}{l}726.2361^{* * *} \\
118.8045\end{array}$ & $\begin{array}{l}688.4193^{* * *} \\
125.9622\end{array}$ & $\begin{array}{l}983.0803^{* * *} \\
137.6933\end{array}$ & $\begin{array}{c}880.0015^{* * *} \\
93.69028\end{array}$ & $\begin{array}{l}926.5855^{* * *} \\
186.7062\end{array}$ \\
\hline Establishment's articles knowledge stock, lagged $(100 s)^{a}$ & $\begin{array}{l}-24.93885^{* *} \\
9.375619\end{array}$ & $\begin{array}{l}-2109.438^{*} \\
972.7733\end{array}$ & $\begin{array}{l}-158.1004^{* *} \\
56.17968\end{array}$ & $\begin{array}{l}-132.8382^{* *} \\
45.15973\end{array}$ & $\begin{array}{l}-1888.396 \\
1136.126\end{array}$ & $\begin{array}{l}128.2884^{* *} \\
44.7206\end{array}$ \\
\hline $\begin{array}{l}\text { Star scientist article authorships as or with establishment } \\
\text { employee(s), total for given year, lagged }\end{array}$ & $\begin{array}{l}1.88874^{*} \\
.8228666\end{array}$ & $\begin{array}{l}34.80571 \\
27.74784\end{array}$ & $\begin{array}{l}8.014322 \\
11.07739\end{array}$ & $\begin{array}{l}18.0666^{* *} \\
6.179855\end{array}$ & $\begin{array}{l}-487.3697 \\
251.9822\end{array}$ & $\begin{array}{l}-13.97503 \\
21.82966\end{array}$ \\
\hline $\begin{array}{l}\text { University co-authorship dummy (=1 if establishment has had } \\
\text { any university co-author(s) up through current year), lagged }\end{array}$ & $\begin{array}{l}439.5949 * * * \\
59.04522\end{array}$ & $\begin{array}{l}96.7463^{* *} \\
36.50101\end{array}$ & $\begin{array}{l}221.4422^{* * *} \\
49.03057\end{array}$ & $\begin{array}{c}386.295^{* * *} \\
61.36374\end{array}$ & $\begin{array}{l}-16.57283 \\
55.0339\end{array}$ & $\begin{array}{l}225.9827^{* * *} \\
50.89043\end{array}$ \\
\hline SBIR grants to establishment in the year, lagged ${ }^{c}$ & $\begin{array}{l}.0152974^{* * *} \\
.0024416\end{array}$ & $\begin{array}{l}-.0411286 \\
.0411626\end{array}$ & $\begin{array}{l}.0897944^{* *} \\
.0290813\end{array}$ & $\begin{array}{l}.0226667^{* * *} \\
.005057\end{array}$ & $\begin{array}{l}.0219206 * * \\
.0082602\end{array}$ & $\begin{array}{l}.0513559 * * * \\
.0107646\end{array}$ \\
\hline Constant & $\begin{array}{c}-3486.355^{* * *} \\
484.3491\end{array}$ & $\begin{array}{l}-2637.788^{* * *} \\
398.3004\end{array}$ & $\begin{array}{l}-2551.758^{* * *} \\
490.2536\end{array}$ & $\begin{array}{l}-3265.486 * * * \\
455.4511\end{array}$ & $\begin{array}{l}-3571.824^{* * *} \\
\quad 361.469\end{array}$ & $\begin{array}{l}-3416.867 * * * \\
637.2583\end{array}$ \\
\hline $\begin{array}{l}F(11, n-11) \text { for all coefficients }{ }^{d}=0 \\
\text { number of observations }\end{array}$ & $\begin{array}{l}5.79 * * * \\
1133155\end{array}$ & $\begin{array}{l}5.04^{* * *} \\
369088\end{array}$ & $\begin{array}{l}3.05^{* * *} \\
278960\end{array}$ & $\begin{array}{l}5.32^{* * *} \\
407178\end{array}$ & $\begin{array}{l}11.14^{* * *} \\
2342042\end{array}$ & $\begin{array}{l}3.41^{* * *} \\
527193\end{array}$ \\
\hline
\end{tabular}

Notes: The estimated coefficients are reported above their italicized standard errors.

*Significantly different from 0 at the 5-percent level. ${ }^{* *}$ Significant at the 1-percent level. ${ }^{* * *}$ Significant at the 0.1 -percent level.

Estimates are for Tobit regressions with robust standard errors. The regressands are amounts of investments by venture capital firms in the establishment in the year, with multi-establishment firm investments divided equally among known establishments.

a. Knowledge stocks are calculated by adding the two-year-window-citations-weighted count of articles or patents to 0.8 times the previous year's knowledge stock value (reduced by a conventional $20 \% /$ year depreciation rate).

b. Patents refer to all patents that were granted by the end of 2005 which were applied for in the current year.

c. The amounts of venture capital investment and SBIR grants received are measured as 3-year moving averages dated by the last of the 3 years. After lagging this is the average amount over the 3 years prior to the current year.

d. All regressions also include the control variables (coefficients not reported here but available from first author): entry dummy (1 in year firm enters, otherwise 0), establishment age, year dummies for 2003, 2004, 2005 (controls for patents applied for but not granted by the end of 2005).

\subsection{Private Firms Going Public}

If venture capital firms are efficient allocators of capital, one would expect the same predictors to do well for both obtaining venture capital and for going public, the biggest source of payoff for venture capitalists. However, only one of their apparent main criteria - non-patent references on the establishment's patents - have significantly positive coefficients for all six S\&T areas as reported in Table 6. The only other similarly strong predictor is the amount of money invested by the venture capitalists. In addition, the patent knowledge stock and tied stars scientists have three significantly positive coefficients and the university co-authorship has two. 
All other coefficients are not significantly different from zero. However, we had to drop either venture capital investments or SBIR grants to get the estimator to converge, presumably due to multicollinearity not apparent in the low bilateral correlations. Venture capital had the better fit and was selected as the included variable. We are left with a puzzle: Venture capitalists or their money seem to do a good job at enabling firms to go public, but the criteria that they appear to use to allocate those funds are only loosely connected to those that predict when and if a firm will go public.

Table 6: Initial Public Offerings by Private Firm Establishments

Probit Analysis with Robust Standard Errors, Explanatory Variables Lagged One Year, 19822005

Establishment's patents knowledge stock, lagged (100s) ${ }^{\mathrm{a}, \mathrm{b}}$
Non-patent reference dummy (=1 if establishment has at least
one patent with non-patent references in given year), lagged
Establishment's articles knowledge stock, lagged (100s)
Star scientist article authorships as or with establishment
employee(s), total for given year, lagged
University co-authorship dummy (=1 if establishment has had
any university co-author(s) up through current year), lagged
Amount of venture capital granted to establishment in the
year, lagged ${ }^{c}$
Constant
$\chi^{2}(11)$ for all coefficients ${ }^{d}=0$
number of observations

\begin{tabular}{|c|c|c|c|c|c|}
\hline \multicolumn{6}{|c|}{ Science and Technology Areas ${ }^{d}$} \\
\hline $\begin{array}{c}\text { Bio/Chem/ } \\
\text { Med }\end{array}$ & $\begin{array}{c}\text { Computing/ } \\
\text { IT }\end{array}$ & $\begin{array}{c}\text { Nanotech- } \\
\text { nology }\end{array}$ & $\begin{array}{l}\text { Semicon- } \\
\text { ductors }\end{array}$ & $\begin{array}{c}\text { Other } \\
\text { Engineer }\end{array}$ & $\begin{array}{l}\text { Other } \\
\text { Science }\end{array}$ \\
\hline $.2295318 * * *$ & $.0395198 * *$ & .0508119 & -.0610266 & $.1050525 * * *$ & .2033254 \\
\hline .0473728 & .0134993 & .0532491 & .0768598 & .0119914 & .1164176 \\
\hline $.6026041 * * *$ & $.4525441 * * *$ & $.4000756 * * *$ & $.5838579 * * *$ & $.4146094 * * *$ & $.4642197 * * *$ \\
\hline .0241361 & .035128 & .0319697 & .0643398 & .0222389 & .0375465 \\
\hline-.0006188 & -.1779785 & .0685395 & -.0022525 & .4046312 & .0343744 \\
\hline .0064167 & .1647992 & .0389699 & .0113039 & .345689 & .0325065 \\
\hline $.0016168 * * *$ & $.0201115^{*}$ & -.0077293 & .0025811 & -.0157377 & $.0378345^{* *}$ \\
\hline .0002942 & .0082216 & .0067788 & .0023126 & .0273145 & .0124996 \\
\hline $.0658081^{* *}$ & -.0997033 & -.0916443 & $.0809944 *$ & -.0807426 & .0332488 \\
\hline .023189 & .0579794 & .0603068 & .0389524 & .0641172 & .0433828 \\
\hline $.0001889 * * *$ & $.0001358 * * *$ & $.0002204^{* * *}$ & $.0001283^{* * *}$ & $.0001874 * * *$ & $.0001433 * * *$ \\
\hline .0000347 & .000027 & .0000455 & .0000324 & .0000375 & .0000427 \\
\hline$-2.861877 * * *$ & $-2.628801 * * *$ & $-2.619442 * * *$ & $-2.896201 * * *$ & $-2.960972^{* * *}$ & $-2.83716 * * *$ \\
\hline .0172825 & .0224596 & .0235106 & .0263861 & .0122139 & .0232244 \\
\hline $1151.54 * * *$ & $566.62 * * *$ & $398.93 * * *$ & $225.14^{* * *}$ & $1113.24^{* * *}$ & $498.42 * * *$ \\
\hline 1045995 & 337827 & 254017 & 376830 & 2180708 & 489326 \\
\hline
\end{tabular}

Notes: The estimated coefficients are reported above their italicized standard errors.

*Significantly different from 0 at the 5-percent level. ${ }^{* *}$ Significant at the 1-percent level. ${ }^{* * *}$ Significant at the 0.1-percent level.

Estimates are for probit regressions with robust standard errors. The regressands are an indicator variable $=1$ in the year the firm makes its initial public offering and 0 otherwise. The data consists of all US establishments of firms not listed on any US exchange in the prior year.

a. Knowledge stocks are calculated by adding the two-year-window-citations-weighted count of articles or patents to 0.8 times the previous year's knowledge stock value (reduced by a conventional $20 \% /$ year depreciation rate).

b. Patents refer to all patents that were granted by the end of 2005 which were applied for in the current year.

c. The amounts of venture capital investment and SBIR grants received are measured as 3-year moving averages dated by the last of the 3 years. After lagging this is the average amount over the 3 years prior to the current year.

d. All regressions also include the control variables (coefficients not reported here but available from first author): entry dummy (1 in year firm enters, otherwise 0 ), establishment age, year dummies for 2003, 2004, 2005 (controls for patents applied for but not granted by the end of 2005). 


\section{Conclusions and Implications}

In the analyses reported in Tables 3-6, we examined across six S\&T areas the effects of lagged values of seven explanatory variables on four different measures of high-tech firm success: publishing scientific articles, obtaining patents, attracting venture capital investments, and going public. Referring back to the visual summary in Figure 1, three of the four firm success variables are used in lagged or lagged-accumulated form in explaining the other success variables. Among the other four variables, whether or not the firm has yet applied for patents with non-patent references, whether or not the firm has a history of ever publishing with university co-authors, and the number of stars authoring as or with firm employees are significantly positive and never significantly negative for all or some of the S\&T fields. The use of non-patent references is the most robust of these three variables, with a history of firmuniversity co-authorship a close second. In contrast, receiving SBIR grants is only robustly positive for attracting venture capital investments. The accumulated citation-weighted patents knowledge stock increases publishing, venture capital investments, and the probability of going public, but the accumulated citation-weighted articles knowledge stock does so for venture capital and going public only as it is reflected in a higher citation-weighted patents knowledge stock.

We interpret the non-patent reference and university co-authorship variables as indicators of whether the firm has adopted the new model with more autonomy to firm scientists and more openness to transfers of tacit knowledge from and to university scientists via working together. Although we have defined them as "if ever before" variables, there is inevitably an element of indication of actual tacit knowledge transfer if their value is 1 so some ambiguity in our interpretation cannot be avoided. On the other hand, star articles are not only an indicator of scientific strength, as we have argued, but also indicate a new model for firms. We only hope that the results presented here are persuasive evidence that it is worth searching for better variables that can more definitively distinguish between scientific strength and adoption of the model that promotes that strength.

\subsection{Implications}

We all see signs of increasing closeness between basic science and industrial innovation, but then use the mechanisms that increase this closeness as mere signals or indicators rather than what they are: institutionally-situated devices for evolutionary reconstruction of these very different forms of intellectual property to provide the kind of cross-support that alters, and possibly strengthens, both kinds. We find especially strong support for quality enhancement of the highly codified patents from incorporating basic science - which contains more tacit knowledge - via non-patent references to scientific articles and scientific materials (e.g., the report of GenBlast search results). But tacit knowledge travels in people, and not well otherwise, and thus co-authoring by firm scientists with any university scientist who works with relevant tacit knowledge - and sometimes with stars also - is the main mechanism for importing tacit 
knowledge that is close to academic discovery, and also independently boosts firm success across most science and technology areas (Darby and Zucker 1999).

We find, as have others earlier, that patenting increases publishing (Azoulay, Ding and Stewart 2009), even for those academic scientists directly involved in commercialization with firms (Zucker and Darby 2007). Confirming Mansfield's (1995) survey results on the importance top scientists place on their work with firms as a source of ideas for their government-funded basic research, Evans (2010) finds that increased contact between universities and firms stimulate the production of new ideas, ideas which are different enough - and diverge from accepted theory enough - that they would otherwise have trouble gaining traction in the academic and related grant world. That is why firm-university collaborative articles are more likely to be highly cited (Powell, White, Koput, Owen-Smith 2005).

When we received our first NSF grant in the late 1980s to explore biotechnology startups, we thought, along with most of academe, that these firms would be a black hole for novel science - ideas would be fed into the firm but never come out publicly again. Our hypothesis was completely refuted by the data, firm-university collaborations were mutually strengthening and our hypothesized implosion was instead an explosion of scientific advance that is still going strong: a virtuous circle instead of a vicious one (Zucker and Darby 2007). Here we also found intriguing traces of new micro-institutional mechanisms for combining tacit and formally deed knowledge in transformative ways: the tacit in research articles, the deeded in patents.

\section{References}

[1] Aghion, Philippe; Howitt, Peter (1992). "A Model of Growth Through Creative Destruction". Econometrica 60 (2): 323-351.

[2] Azoulay, Pierre, Ding, Waverly and Stuart, Toby (2009) “The Impact of Academic Patenting on the Rate, Quality and Direction of (Public) Research Output,” The Journal of Industrial Economics, December, 57(4), 637-676.

[3] Azoulay, Pierre, Graff Zivin, Joshua S., and Wang, Jialan (2010) "Superstar Extinction,” Quarterly Journal of Economics, 25, 2010: 549-589.

[4] Azoulay, Pierre, Graff Zivin, Joshua S., Sampat, Bhaven N. (2014) "The Diffusion of Scientific Knowledge across Time and Space: Evidence from Professional Transitions for the Superstars of Medicine," in The Rate and Direction of Inventive Activity: A New Agenda, J Lerner and S Stern (Eds.), forthcoming.

[5] Baird, Davis (2007) Thing Knowledge: A Philosophy of Scientific Instruments. Berkeley, CA: University of California Press.

[6] Baker, Ted, Miner, Anne S., Eesley, Dale T. (2003) "Improvising Firms: Bricolage, Account Giving and Improvisational Competencies in the Founding Process,” Research Policy, February, 32(2), 255-276.

[7] Bioscan, Volumes 3-11, 1989-1997. 
[8] Branstetter, Lee, "Exploring the Link Between Academic Science and Industrial Innovation,” Annales d'Economie et Statistique, July/December 2005, 79/80, 119-142.

[9] Branstetter, Lee, Ogura, Yoshiaki (2005) "Is academic science driving a surge in industrial innovation? Evidence from patent citations," National Bureau of Economics Research Working Paper No. 12172, August.

[10] Cheung, Steven N. S. (1982) "Property Rights in Trade Secrets," Economic Inquiry, January, 20(1), 40-53.

[11] Crane, Diana (1969) "Social Structure in a Group of Scientists: A Test of the Invisible College Hypothesis,” American Sociological Review, June, 34(3), 335-52.

[12] Crane, Diana (1972) Invisible Colleges: Diffusion of Knowledge in Scientific Communities. Chicago IL: University of Chicago Press.

[13] Darby, Michael R., Zucker, Lynne G. (1999) California's Science Base: Size, Quality and Productivity, Sacramento, CA: California Council on Science and Technology.

[14] Darby, Michael R., Zucker, Lynne G. (2005) "Grilichesian Breakthroughs: Inventions of Methods of Inventing in Nanotechnology and Biotechnology," Annales d'Economie et Statistique, July/December 2005, 79/80, 143-164.

[15] Dunn, Peter M. (1999) "The Chamberlen Family (1560-1728) and Obstetric Forceps,” Archives of Disease in Childhood-Fetal and Neonatal Edition, November 81(3), F232F235.

[16] Evans, James A. (2010) "Industry Induces Academic Science to Know Less about More,” American Journal of Sociology, September, 116 (2), 389-452.

[17] Jaffe, Adam B. (1989) "Real Effects of Academic Research," American Economic Review, December, 79(5), 957-970.

[18] Jensen, Richard A., Thursby, Marie C. (2001) "Proofs and Prototypes for Sale: The Tale of University Licensing,” American Economic Review, March, 91(1), 240-259.

[19] Johnson, Kenneth P., Kort, John R. (2004) "2004 Redefinition of the BEA Economic Areas,” Survey of Current Business, November, pp. 68-75.

[20] Kornhauser, William (1962) Scientists in Industry: Conflict and Accommodation. Berkeley, CA: University of California Press.

[21] Kreiner, Kristian, Schultz, Majken (1993) "Informal Collaboration in R\&D: The Formation of Networks across Organizations.” Organization Studies, March, 14(2), 189209.

[22] Liebeskind, Julia Porter, Oliver, Amalya, Zucker, Lynne G., Brewer, Marilynn B. (1996) "Social Networks, Learning, and Flexibility: Sourcing Scientific Knowledge in New Biotechnology Firms.” Organization Science, July/August, 7, 428-443.

[23] MacKenzie, Donald, and Spinardi, Graham (1995) "Tacit Knowledge, Weapons Design, and the Uninvention of Nuclear Weapons,” American Journal of Sociology, July, 101(1), 44-99. 
[24] Mansfield, Edwin (1995) "Academic Research Underlying Industrial Innovations: Sources, Characteristics, and Financing," Review of Economics and Statistics, February, 77(1), 55-65.

[25] Marcson, Simon (1960). The Scientist in American industry: Some Organizational Determinants in Manpower Utilization (No. 99). Published in cooperation with the Industrial Relations Section, Dept. of Economics, Princeton University, by Harper.

[26] Marcson, Simon (1961) “Organization and Authority in Industrial Research,” Social Forces, October, 40(1), 72-80.

[27] Narin, Francis, Hamilton, Kimberly S., Olivastro, Dominic (1997) "The Increasing Linkage between U.S. Technology and Public Science,” Research Policy, 26(3), 317-330.

[28] National Research Council (1995) Research-Doctorate Programs in the United States: Data Set, machine-readable data base, Washington, DC: National Academy Press.

[29] Oliver, Amalya L. (2004) "Biotechnology Entrepreneurial Scientists and Their Collaborations,” Research Policy, May, 33(4), 583-597.

[30] Oliver, Amalya L. (2004) Networks for Learning and Knowledge Creation, Cambridge, U.K.: Cambridge University Press.

[31] Oliver, Amalya L., Montgomery, Kathleen, (2000) "Creating a Hybrid Organizational Form from Parental Blueprints: The Emergence and Evolution of Knowledge Firms," Human Relations, January. 53(1), 33-56.

[32] Pisano, Gary P. (1990) "The R\&D Boundaries of the Firm: An Empirical Analysis," Administrative Science Quarterly, March, 35(1), 153-176.

[33] Polanyi, Michael (1962) Personal Knowledge: Towards a Post-Critical Philosophy, Chicago, IL: University of Chicago Press.

[34] Powell, Walter W., White, Douglas R., Koput, Kenneth W., Owen-Smith, Jason (2005) "Network Dynamics and Field Evolution: The Growth of Interorganizational Collaboration in the Life Sciences," American Journal of Sociology, January, 110(4), 1132-1205.

[35] Romanelli, Elaine (1991) "The Evolution of New Organizational Forms," Annual Review of Sociology, 17, 79-103.

[36] Schumpeter, Joseph A. (1942) Capitalism, Socialism, and Democracy, 3d ed. New York, NY: Harper and Brothers, 1950 reprint.

[37] Thursby, Jerry G., Thursby, Marie (2002) "Who Is Selling the Ivory Tower? Sources of Growth in University Licensing,” Management Science, January, 48(1), 90-104.

[38] U.K. Patent Office (2004) "Peter Chamberlen or Chamberlan," from Patent Office History material, downloaded on November 14, 2004, from: http://freepages.history.rootsweb.ancestry.com/ enzedders/chamberlen.htm.

[39] Zucker, Lynne G., Darby, Michael R. (1996) "Star Scientists and Institutional Transformation: Patterns of Invention and Innovation in the Formation of the Biotechnology Industry," Proceedings of the National Academy of Sciences, November 12, 93(23), 12709-12716. 
[40] Zucker, Lynne G., Darby, Michael R. (1997) "Present at the Biotechnological Revolution: Transformation of Technical Identity for a Large Incumbent Pharmaceutical Firm," Research Policy, December, 26(4\&5), 429-446.

[41] Zucker, Lynne G., Darby, Michael R. (1999) California's Inventive Activity: Patent Indicators of Quantity, Quality, and Organizational Origins, California Council on Science and Technology.

[42] Zucker, Lynne G., Darby, Michael R. (2001) "Capturing Technological Opportunity Via Japan's Star Scientists: Evidence from Japanese Firms' Biotech Patents and Products," Journal of Technology Transfer, January, 26(1/2), 37-58.

[43] Zucker, Lynne G., Darby, Michael R. (2007) "Virtuous Circles in Science and Commerce,” Papers in Regional Science, August, 86(3), 445-471.

[44] Zucker, Lynne G., Darby, Michael R. (2014) "Movement of Star Scientists and Engineers and High-Tech Firm Entry," Annals of Economics and Statistics (Annales d'Economie et Statistique), this issue.

[45] Zucker, Lynne G., Darby, Michael R., Armstrong, Jeff (1998) “Geographically Localized Knowledge: Spillovers or Markets?” Economic Inquiry, January, 36(1), 65-86.

[46] Zucker, Lynne G., Darby, Michael R., Armstrong, Jeff (2002) “Commercializing Knowledge: University Science, Knowledge Capture, and Firm Performance in Biotechnology.” Management Science, January, 48(1), 138-153.

[47] Zucker, Lynne G., Darby, Michael R., Brewer, Marilynn B. (1998) "Intellectual Human Capital and the Birth of U.S. Biotechnology Enterprises," American Economic Review, March, 88(1), 290-306.

[48] Zucker, Lynne G., Darby, Michael R., Brewer, Marilynn B., Peng, Yusheng (1996) "Collaboration Structure and Information Dilemmas in Biotechnology: Organizational Boundaries as Trust Production,” in Roderick M. Kramer and Tom R. Tyler, eds., Trust in Organizations, Thousand Oaks, CA: Sage.

[49] Zucker, Lynne G., Darby, Michael R., Fong, Jason (2014) "Communitywide Database Designs for Tracking Innovation Impact: COMETS, STARS and Nanobank," Annals of Economics and Statistics (Annales d'Economie et Statistique), this issue.

[50] Zucker, Lynne G., Darby, Michael R., Torero, Máximo (2002) "Labor Mobility from Academe to Commerce.” Journal of Labor Economics, 20(3), 629-660. 


\section{Appendix: Correlation Coefficients for the Variables}

\section{Table A1. Correlation Coefficients for Full Sample}

\begin{tabular}{|c|c|c|c|c|c|c|c|c|c|c|c|c|c|c|c|c|c|c|}
\hline Variable & $\begin{array}{l}\begin{array}{l}\text { Articles } \\
\text { in given } \\
\text { year }\end{array} \\
\end{array}$ & $\begin{array}{l}\text { Patents } \\
\text { in given } \\
\text { year }\end{array}$ & $\begin{array}{l}\begin{array}{l}\text { Articles } \\
\text { knowldg. } \\
\text { stock }\end{array} \\
\end{array}$ & $\begin{array}{l}\text { Patents } \\
\text { knowldg. } \\
\text { stock }\end{array}$ & $\begin{array}{l}\text { Venture } \\
\text { capital }\end{array}$ & $\begin{array}{l}\text { SBRR } \\
\text { grants }\end{array}$ & $\begin{array}{l}\begin{array}{l}\text { Non- } \\
\text { patent } \\
\text { refs. }\end{array} \\
\end{array}$ & $\begin{array}{l}\text { Star } \\
\text { scientist } \\
\text { ties }\end{array}$ & $\begin{array}{c}\text { Univer- } \\
\text { ts sity co- } \\
\text { authors }\end{array}$ & $\begin{array}{l}\begin{array}{l}\text { Articles } \\
\text { in given } \\
\text { year }\end{array} \\
\end{array}$ & $\begin{array}{l}\text { Patents } \\
\text { in given } \\
\text { year }\end{array}$ & $\begin{array}{l}\text { Articles } \\
\text { knowldg. } \\
\text { stock }\end{array}$ & $\begin{array}{l}\text { Patents } \\
\text { g. knowldg } \\
\text { stock }\end{array}$ & $\begin{array}{l}\text { Venture } \\
\text { capital } \\
\end{array}$ & $\begin{array}{l}\text { SBIR } \\
\text { grants }\end{array}$ & $\begin{array}{l}\begin{array}{l}\text { Non- } \\
\text { patent } \\
\text { refs. }\end{array} \\
\end{array}$ & $\begin{array}{l}\text { Star } \\
\text { scientists } \\
\text { ties }\end{array}$ & $\begin{array}{l}\text { Univer- } \\
\text { s sity co- } \\
\text { authors }\end{array}$ \\
\hline \multirow[b]{2}{*}{$\begin{array}{l}\text { Articles authored by establishment's employees published in } \\
\text { given year, fractional amounts rounded up to next integer } \\
\text { Patents }{ }^{\mathrm{b}} \text { assigned to the firm allocated to establishment by } \\
\text { residence of inventor(s), fractional amounts rounded up }\end{array}$} & \multicolumn{9}{|c|}{ Biology/Chemistry/Medicine } & \multicolumn{9}{|c|}{ Computing/Information Technology } \\
\hline & 0.1864 & 1 & & & & & & & & 0.2198 & 1 & & & & & & & \\
\hline Establishment's articles knowledge stock ${ }^{\mathrm{a}}$ & 0.9228 & 0.1764 & 1 & & & & & & & 0.9180 & 0.2319 & 1 & & & & & & \\
\hline Establishment's patents knowledge stock $\mathrm{k}^{\mathrm{a}, \mathrm{b}}$ & 0.2502 & 0.8200 & 0.2585 & 1 & & & & & & 0.2683 & 0.8181 & 0.293 & 1 & & & & & \\
\hline $\begin{array}{l}\text { Venture capital investments received by the establishment in } \\
\text { the year }\end{array}$ & 0.0030 & 0.0065 & 0.0020 & 0.0078 & 1 & & & & & -0.0003 & 0.0022 & -0.0004 & 40.0022 & 1 & & & & \\
\hline SBIR grants to establishment in the year ${ }^{c}$ & 0.0100 & 0.0036 & 0.0073 & 0.0033 & 0.0061 & 1 & & & & 0.0026 & -0.0006 & 0.0016 & 0.0002 & -0.0002 & 1 & & & \\
\hline $\begin{array}{l}\text { Non-patent reference dummy }(=1 \text { if establishment has at least } \\
\text { one patent with non-patent references in given year) }\end{array}$ & 0.0867 & 0.2670 & 0.0816 & 0.2281 & 0.0151 & 0.0234 & 1 & & & 0.0687 & 0.2024 & 0.0647 & 0.1704 & 0.0102 & -0.0008 & 1 & & \\
\hline $\begin{array}{l}\text { Star scientist article authorships as or with establishment } \\
\text { employee(s), total for given year }\end{array}$ & 0.3780 & 0.0864 & 0.3569 & 0.1143 & 0.0012 & 0.0113 & 0.0363 & 1 & & 0.8968 & 0.2102 & 0.9121 & 0.2239 & -0.0002 & 0.0017 & 0.0537 & 1 & \\
\hline \multirow{2}{*}{ any university co-author(s) up through current year) } & 0.0842 & 0.0348 & 0.0846 & 0.0553 & 0.0081 & 0.0443 & 0.0067 & 0.0505 & 1 & 0.1097 & 0.0758 & 0.0960 & 0.1003 & 0.0018 & 0.0297 & 0.0276 & 0.0646 & 1 \\
\hline & \multicolumn{9}{|c|}{ Nanotechnology } & \multicolumn{9}{|c|}{ Semiconductors/Integrated Circuits } \\
\hline $\begin{array}{l}\text { Articles authored by establishment's employees published in } \\
\text { given year, fractional amounts rounded up to next integer } \\
\text { Patents } s^{b} \text { assigned to the firm allocated to establishment by } \\
\text { residence of inventor(s), fractional amounts rounded up }\end{array}$ & 0.2036 & 1 & & & & & & & & 0.0646 & 1 & & & & & & & \\
\hline Establishment's articles knowledge stock ${ }^{a}$ & 0.8505 & 0.2120 & 1 & & & & & & & 0.8560 & 0.0906 & 1 & & & & & & \\
\hline Establishment's patents knowledge stocka,b & 0.2985 & 0.7346 & 0.3469 & 1 & & & & & & 0.0811 & 0.8435 & 0.1098 & 1 & & & & & \\
\hline $\begin{array}{l}\text { Venture capital investments received by the establishment in } \\
\text { the year }\end{array}$ & 0.0003 & 0.0044 & 0.0000 & 0.0067 & 1 & & & & & 0.0001 & 0.0063 & 0.0000 & 0.0060 & 1 & & & & \\
\hline SBIR grants to establishment in the year ${ }^{c}$ & 0.0017 & -0.0004 & 0.0009 & 0.0020 & 0.0026 & 1 & & & & 0.0027 & -0.0003 & 0.0024 & -0.0002 & $2 \quad 0.0011$ & 1 & & & \\
\hline $\begin{array}{l}\text { Non-patent reference dummy }(=1 \text { if establishment has at least } \\
\text { one patent with non-patent references in given year) }\end{array}$ & 0.0474 & 0.1774 & 0.0466 & 0.1701 & 0.0101 & -0.0010 & 1 & & & 0.0853 & 0.1853 & 0.0931 & 0.1728 & 0.0120 & 0.0028 & 1 & & \\
\hline $\begin{array}{l}\text { Star scientist article authorships as or with establishment } \\
\text { employee(s), total for given year } \\
\text { University c-atuthorship dummy }=1 \text { if establishment has had }\end{array}$ & 0.8327 & 0.1482 & 0.8737 & 0.2349 & 0.0000 & -0.0001 & 0.0337 & 1 & & 0.9025 & 0.0703 & 0.9225 & 0.0871 & 0.0001 & 0.0014 & 0.0812 & 1 & \\
\hline \multirow{2}{*}{$\begin{array}{l}\text { University co-authorship dummy ( }=1 \text { if establishment has had } \\
\text { any university co-author(s) up through current year) }\end{array}$} & 0.0863 & 0.0866 & 0.0908 & 0.1435 & 0.009 & 0.0319 & 0.0468 & 0.0601 & 1 & 0.0395 & 0.0255 & 0.0451 & 0.0316 & 0.0089 & 0.0392 & 0.0430 & 0.0365 & 1 \\
\hline & \multicolumn{9}{|c|}{ Other Engineering } & \multicolumn{9}{|c|}{ Other Science } \\
\hline $\begin{array}{l}\text { Articles authored by establishment's employees published in } \\
\text { given year, fractional amounts rounded up to next integer } \\
\text { Patents } s^{a} \text { assigned to the firm allocated to establishment by } \\
\text { residence of inventor(s), fractional amounts rounded up }\end{array}$ & 0.1531 & 1 & & & & & & & & 0.0656 & 1 & & & & & & & \\
\hline Establishment's articles knowledge stock ${ }^{a}$ & 0.8157 & 0.2056 & 1 & & & & & & & 0.7962 & 0.0765 & 1 & & & & & & \\
\hline Establishment's patents knowledge stock ${ }^{\mathrm{a}, \mathrm{b}}$ & 0.1675 & 0.8439 & 0.2358 & 1 & & & & & & 0.0877 & 0.7918 & 0.1136 & 1 & & & & & \\
\hline $\begin{array}{l}\text { Venture capital investments received by the establishment in } \\
\text { the year }\end{array}$ & 0.0000 & 0.0069 & -0.0002 & 0.0075 & 1 & & & & & 0.0037 & 0.0197 & 0.0028 & 0.0141 & 1 & & & & \\
\hline SBIR grants to establishment in the year ${ }^{c}$ & 0.0074 & 0.0007 & 0.0072 & 0.001 & 0.0004 & 1 & & & & 0.0036 & 0.0099 & 0.0049 & 0.0083 & 0.0018 & 1 & & & \\
\hline $\begin{array}{l}\text { Non-patent reference dummy }(=1 \text { if establishment has at least } \\
\text { one patent with non-patent references in given year) }\end{array}$ & 0.0362 & 0.2085 & 0.0397 & 0.1729 & 0.0156 & 0.0057 & 1 & & & 0.0462 & 0.2962 & 0.0579 & 0.2438 & 0.0198 & 0.0299 & 1 & & \\
\hline $\begin{array}{l}\text { Star scientist article authorships as or with establishment } \\
\text { employee(s), total for given year }\end{array}$ & 0.3835 & 0.0808 & 0.3317 & 0.0954 & -0.0001 & 0.0005 & 0.0160 & 1 & & 0.5753 & 0.1076 & 0.5151 & 0.1411 & 0.0027 & 0.0025 & 0.0432 & 1 & \\
\hline $\begin{array}{l}\text { University co-authorship dummy ( }=1 \text { if establishment has had } \\
\text { any university co-author(s) up through current year) }\end{array}$ & 0.1590 & 0.0842 & 0.1556 & 0.1123 & 0.0016 & 0.0183 & 0.0328 & 0.0588 & 1 & 0.1168 & 0.0381 & 0.1435 & 0.0601 & 0.0018 & 0.0292 & 0.0040 & 0.1336 & 1 \\
\hline
\end{tabular}


Notes: a. Knowledge stocks are calculated by adding the two-year-window-citations-weighted count of articles or patents to 0.8 times the previous year's knowledge stock value (reduced by a conventional $20 \%$ /year depreciation rate).

b. Patents refer to all patents that were granted by the end of 2005 which were applied for in the current year.

c. The amounts of venture capital investment and SBIR grants received are measured as 3-year moving averages dated by the last of the 3 years. After lagging this is the average amount over the 3 years prior to the current year. 
Table A2. Correlation Coefficients for Private-Firms Sample

\begin{tabular}{|c|c|c|c|c|c|c|c|c|c|c|c|c|c|c|c|c|}
\hline Variable & $\begin{array}{l}\text { Articles } \\
\text { knowldg. } \\
\text { stock }\end{array}$ & $\begin{array}{l}\text { Patents } \\
\text { knowldg. } \\
\text { stock }\end{array}$ & $\begin{array}{l}\text { IPO } \\
\text { dummy }\end{array}$ & $\begin{array}{l}\text { Venture } \\
\text { capital }\end{array}$ & $\begin{array}{l}\text { SBIR } \\
\text { grants }\end{array}$ & $\begin{array}{l}\text { Non- } \\
\text { patent } \\
\text { refs. }\end{array}$ & $\begin{array}{l}\text { Star } \\
\text { scientists } \\
\text { ties }\end{array}$ & $\begin{array}{l}\text { Univer- } \\
\text { sity co- } \\
\text { authors }\end{array}$ & $\begin{array}{l}\text { Articles } \\
\text { knowldg. } \\
\text { stock }\end{array}$ & $\begin{array}{l}\text { Patents } \\
\text { knowldg. } \\
\text { stock }\end{array}$ & $\begin{array}{l}\text { IPO } \\
\text { dummy }\end{array}$ & $\begin{array}{l}\text { Venture } \\
\text { capital }\end{array}$ & $\begin{array}{l}\text { SBIR } \\
\text { grants }\end{array}$ & $\begin{array}{l}\text { Non- } \\
\text { patent } \\
\text { refs. }\end{array}$ & $\begin{array}{l}\text { Star } \\
\text { scientists } \\
\text { ties }\end{array}$ & $\begin{array}{l}\text { Univer- } \\
\text { sity co- } \\
\text { authors }\end{array}$ \\
\hline & \multicolumn{8}{|c|}{ Biology/Chemistry/Medicine } & \multicolumn{8}{|c|}{ Computing/Information Technology } \\
\hline Establishment's articles knowledge stock ${ }^{a}$ & 1 & & & & & & & & 1 & & & & & & & \\
\hline Establishment's patents knowledge stock ${ }^{\mathrm{a}, \mathrm{b}}$ & 0.2744 & 1 & & & & & & & 0.3497 & 1 & & & & & & \\
\hline $\begin{array}{l}\text { Initial Public Offering (IPO) dummy (=1 in year firm makes its } \\
\text { initial public offering) }\end{array}$ & 0.0022 & 0.0089 & 1 & & & & & & 0.0063 & 0.0047 & 1 & & & & & \\
\hline $\begin{array}{l}\text { Venture capital investments received by the establishment in } \\
\text { the year }\end{array}$ & 0.0017 & 0.0082 & 0.0417 & 1 & & & & & -0.0005 & 0.0028 & 0.0396 & 1 & & & & \\
\hline SBIR grants to establishment in the year ${ }^{c}$ & 0.0047 & 0.0024 & 0.0076 & 0.0061 & 1 & & & & 0.0019 & 0.0006 & -0.0002 & -0.0002 & 1 & & & \\
\hline $\begin{array}{l}\text { Non-patent reference dummy ( }=1 \text { if establishment has at least } \\
\text { one patent with non-patent references in given year) }\end{array}$ & 0.0720 & 0.2280 & 0.0370 & 0.0144 & 0.0192 & 1 & & & 0.0696 & 0.1692 & 0.0379 & 0.0138 & -0.0006 & 1 & & \\
\hline $\begin{array}{l}\text { Star scientist article authorships as or with establishment } \\
\text { employee(s), total for given year }\end{array}$ & 0.3443 & 0.1159 & 0.0027 & 0.0011 & 0.0092 & 0.0292 & 1 & & 0.9105 & 0.2660 & 0.0071 & -0.0003 & 0.0020 & 0.0563 & 1 & \\
\hline \multirow{2}{*}{$\begin{array}{l}\text { University co-authorship dummy ( }=1 \text { if establishment has had } \\
\text { any university co-author(s) up through current year) }\end{array}$} & 0.0784 & 0.0551 & 0.0031 & 0.0075 & 0.0398 & -0.0012 & 0.0460 & 1 & 0.0994 & 0.0983 & -0.0045 & 0.0017 & 0.0304 & 0.0272 & 0.0650 & 1 \\
\hline & \multicolumn{8}{|c|}{ Nanotechnology } & \multicolumn{8}{|c|}{ Semiconductors/Integrated Circuits } \\
\hline Establishment's articles knowledge stock ${ }^{a}$ & 1 & & & & & & & & 1 & & & & & & & \\
\hline Establishment's patents knowledge stock $\mathrm{a}^{\mathrm{a}, \mathrm{b}}$ & 0.3893 & 1 & & & & & & & 0.1892 & 1 & & & & & & \\
\hline $\begin{array}{l}\text { Initial Public Offering (IPO) dummy (=1 in year firm makes its } \\
\text { initial public offering) }\end{array}$ & 0.0079 & 0.0065 & 1 & & & & & & 0.0068 & 0.0021 & 1 & & & & & \\
\hline $\begin{array}{l}\text { Venture capital investments received by the establishment in } \\
\text { the year }{ }^{c}\end{array}$ & -0.0001 & 0.0092 & 0.0513 & 1 & & & & & -0.0001 & 0.0108 & 0.0279 & 1 & & & & \\
\hline SBIR grants to establishment in the year ${ }^{c}$ & 0.0010 & 0.0023 & -0.0006 & 0.0037 & 1 & & & & 0.0019 & -0.0006 & 0.0043 & 0.0013 & 1 & & & \\
\hline $\begin{array}{l}\text { Non-patent reference dummy ( }=1 \text { if establishment has at least } \\
\text { one patent with non-patent references in given year) }\end{array}$ & 0.0483 & 0.1759 & 0.0398 & 0.0133 & -0.0010 & 1 & & & 0.1030 & 0.2332 & 0.0165 & 0.0127 & -0.0012 & 1 & & \\
\hline $\begin{array}{l}\text { Star scientist article authorships as or with establishment } \\
\text { employee(s), total for given year }\end{array}$ & 0.8511 & 0.2510 & 0.0079 & 0.0002 & -0.0001 & 0.0339 & 1 & & 0.9232 & 0.1476 & 0.0067 & 0.0002 & 0.0013 & 0.0886 & 1 & \\
\hline \multirow{2}{*}{$\begin{array}{l}\text { University co-authorship dummy ( }=1 \text { if establishment has had } \\
\text { any university co-author(s) up through current year) }\end{array}$} & 0.0908 & 0.1574 & -0.0038 & 0.0080 & 0.0328 & 0.0452 & 0.0583 & 1 & 0.0444 & 0.0544 & 0.0043 & 0.0078 & 0.0376 & 0.0450 & 0.0355 & 1 \\
\hline & \multicolumn{8}{|c|}{ Other Engineering } & \multicolumn{8}{|c|}{ Other Science } \\
\hline Establishment's articles knowledge stock ${ }^{\mathrm{a}}$ & 1 & & & & & & & & 1 & & & & & & & \\
\hline Establishment's patents knowledge stock & 0.2177 & 1 & & & & & & & 0.1584 & 1 & & & & & & \\
\hline $\begin{array}{l}\text { Initial Public Offering (IPO) dummy (=1 in year firm makes its } \\
\text { initial public offering) }\end{array}$ & 0.0019 & 0.0072 & 1 & & & & & & 0.0112 & 0.0115 & 1 & & & & & \\
\hline $\begin{array}{l}\text { Venture capital investments received by the establishment in } \\
\text { the year }{ }^{c}\end{array}$ & -0.0002 & 0.0069 & 0.0345 & 1 & & & & & 0.0040 & 0.0198 & 0.0493 & 1 & & & & \\
\hline SBIR grants to establishment in the year ${ }^{c}$ & 0.0070 & 0.0010 & -0.0002 & 0.0006 & 1 & & & & 0.0053 & 0.0092 & 0.0061 & 0.0026 & 1 & & & \\
\hline $\begin{array}{l}\text { Non-patent reference dummy ( }=1 \text { if establishment has at least } \\
\text { one patent with non-patent references in given year) }\end{array}$ & 0.0399 & 0.1711 & 0.0193 & 0.0158 & 0.0057 & 1 & & & 0.0622 & 0.2628 & 0.0227 & 0.0224 & 0.0312 & 1 & & \\
\hline $\begin{array}{l}\text { Star scientist article authorships as or with establishment } \\
\text { employee(s), total for given year }\end{array}$ & 0.3288 & 0.0922 & 0.0012 & -0.0001 & 0.0003 & 0.0161 & 1 & & 0.4725 & 0.1717 & 0.0122 & 0.0035 & 0.0025 & 0.0409 & 1 & \\
\hline $\begin{array}{l}\text { University co-authorship dummy (=1 if establishment has had } \\
\text { any university co-author(s) up through current year) }\end{array}$ & 0.1563 & 0.1134 & -0.0006 & 0.0012 & 0.0171 & 0.0323 & 0.0587 & 1 & 0.1510 & 0.0703 & 0.0050 & 0.0014 & 0.0280 & 0.0032 & 0.1293 & 1 \\
\hline
\end{tabular}


Notes: a. Knowledge stocks are calculated by adding the two-year-window-citations-weighted count of articles or patents to 0.8 times the previous year's knowledge stock value (reduced by a conventional $20 \%$ /year depreciation rate).

b. Patents refer to all patents that were granted by the end of 2005 which were applied for in the current year.

c. The amounts of venture capital investment and SBIR grants received are measured as 3-year moving averages dated by the last of the 3 years. After lagging this is the average amount over the 3 years prior to the current year. 